NBER WORKING PAPER SERIES

\title{
CASH FLOW DURATION AND THE TERM STRUCTURE OF EQUITY RETURNS
}

\author{
Michael Weber \\ Working Paper 22520 \\ http://www.nber.org/papers/w22520 \\ NATIONAL BUREAU OF ECONOMIC RESEARCH \\ 1050 Massachusetts Avenue \\ Cambridge, MA 02138 \\ August 2016
}

I thank Daniel Andrei, Andrew Ang, Malcolm Baker (discussant), Jules van Binsbergen (discussant), Jonathan Berk, Justin Birru (discussant), John Campbell, John Cochrane, Francesco D'Acunto, Kent Daniel, Ian Dew-Becker, Xavier Gabaix, Nicolae Garleanu, Yuriy Gorodnichenko, Robert Hodrick, Brian Johnson, Tim Kroenke, Martin Lettau, Lars Lochstoer, Pier Lopez, Sydney Ludvigson, Hanno Lustig, Rajnish Mehra, Tyler Muir, Stefan Nagel, Marcus Opp, Carolin Pflueger, Matt Ringgenberg, Tano Santos, Florian Schulz, Richard Sloan, Christian Speck, Richard Stanton, Annette Vissing-Jorgensen, Tuomo Vuolteenaho, Johan Walden, Amir Yaron, and seminar participants at the AFA 2016, Arrowstreet Capital, China International Conference, the 15th Colloquium on Financial Markets, Colorado Winter Finance Summit, Hannover, Maastricht, Mannheim, Muenster, the 2015 NBER Asset Pricing Meeting, Tilburg, the 2015 HEC--McGill Winter Finance Workshop, the 25th Australasian Banking and Finance Conference, the 16th SGF conference, and UC Berkeley for their valuable comments. Financial support from the University of Chicago, the Neubauer Family Foundation, and the Fama-Miller Center is also gratefully acknowledged. Stephen Lamb provided excellent research assistance. The views expressed herein are those of the author and do not necessarily reflect the views of the National Bureau of Economic Research.

NBER working papers are circulated for discussion and comment purposes. They have not been peer-reviewed or been subject to the review by the NBER Board of Directors that accompanies official NBER publications.

(C) 2016 by Michael Weber. All rights reserved. Short sections of text, not to exceed two paragraphs, may be quoted without explicit permission provided that full credit, including (C) notice, is given to the source. 
Cash Flow Duration and the Term Structure of Equity Returns

Michael Weber

NBER Working Paper No. 22520

August 2016

JEL No. E43,G12,G14

\title{
ABSTRACT
}

The term structure of equity returns is downward-sloping: stocks with high cash flow duration earn $1.10 \%$ per month lower returns than short-duration stocks in the cross section. I create a measure of cash flow duration at the firm level using balance sheet data to show this novel fact. Factor models can explain only $50 \%$ of the return differential, and the difference in returns is three times larger after periods of high investor sentiment. I use institutional ownership as a proxy for short-sale constraints, and find the negative cross-sectional relationship between cash flow duration and returns is only contained within short-sale constrained stocks.

\author{
Michael Weber \\ Booth School of Business \\ University of Chicago \\ 5807 South Woodlawn Avenue \\ Chicago, IL 60637 \\ and NBER \\ michael.weber@chicagobooth.edu
}




\section{Introduction}

The term structure of equity returns is downward-sloping. van Binsbergen, Brandt, and Koijen (2012) show that a synthetically created short-term asset that only pays dividends in the near-term future has higher returns than the market index, which is a claim to the stream of all future dividends. Their finding is puzzling because all leading asset-pricing models, such as the external habit-formation model of Campbell and Cochrane (1999), the long-run risk model of Bansal and Yaron (2004), or the rare disaster model of Barro (2006) and Gabaix (2012), instead imply an upward-sloping or flat-term structure of equity returns (see Lettau and Wachter (2007)). An active literature develops new equilibrium asset-pricing models to rationalize the downward-sloping term structure (see, e.g., Belo, Collin-Dufresne, and Goldstein (2015) and Ai, Croce, Diercks, and Li (2012)). ${ }^{1}$

van Binsbergen et al. (2012) use a sample from 1996 to 2009 that contains two major recessions and stock market downturns. The term structure of interest rates often inverts during adverse macroeconomics periods. Ait-Sahalia, Karaman, and Mancini (2015) show the term structure of risk premia is downward-sloping during recessions but flat or upwardsloping during normal times. Alternative explanations for the downward-sloping term structure of risk premia are differential taxation between dividends and capital gains (see Schulz (2015)) and market microstructure noise (see Boguth, Carlson, Fisher, and Simutin (2012)).

One avenue for disentangling these potentially conflicting explanations is to wait for twenty years and perform an out-of-sample test. Instead, I tackle this problem by resorting to the cross section of stock returns. Recent equilibrium models typically refer to the value premium to motivate their analysis, and argue growth stocks have high cash flow duration but low returns. Rather than relying on indirect inference via the value premium, I create a direct measure of cash flow duration at the firm level using balance sheet data. I sort stocks into ten portfolios with increasing cash flow duration. Low-duration stocks outperform high-duration stocks by $1.10 \%$ per month, but have lower CAPM betas consistent with

\footnotetext{
${ }^{1}$ See also Croce, Lettau, and Ludvigson (2015); Corhay, Kung, and Schmid (2015); Favilukis and Lin (2016); Lopez, Lopez-Salido, and Vazquez-Grande (2015), and Marfè (2016), among others. van Binsbergen and Koijen (2015) provide an excellent overview of this fast-growing literature.
} 
results in van Binsbergen et al. (2012). Exposure to classical risk factors cannot explain the novel cross section either. ${ }^{2}$ The difference in returns between low- and high-duration stocks is three times larger after periods of high investor sentiment, and excess returns of high-duration stocks load positively on changes in sentiment.

Market participants might be overly optimistic about the prospects of high-duration stocks. Analysts expect stocks with high cash flow duration to grow twice as fast over the following five years compared to low-duration stocks. This difference in growth forecasts shrinks by more than $50 \%$ over the next five years. Analysts seem to extrapolate from past earnings growth into the future. High-duration stocks indeed grew substantially faster in the past than low-duration stocks, but they have the same growth in earnings over the following five years. Standardized earnings surprises corroborate overly excessive growth expectations for high-duration stocks.

Impediments to short selling might explain why rational arbitrageurs do not take sufficiently large short positions in possibly overpriced high-duration stocks. I follow Nagel (2005) and use institutional ownership, the fraction of shares institutions hold, as a proxy for short-sale constraints to test this hypothesis empirically. ${ }^{3}$ I find evidence consistent with mispricing. The spread in excess returns is strongest among stocks that are potentially most short-sale constrained: low-duration stocks outperform high-duration stocks on average by $1.32 \%$ per month in the lowest institutional ownership class. The difference in returns monotonically decreases in institutional ownership to a statistically insignificant $0.15 \%$ per month for potentially unconstrained stocks. Short-sale constraints only matter for high-duration stocks, which are potentially overpriced; they do not matter for short-duration stocks. The results hold for both small and large stocks, but also among value and growth stocks.

My findings complement and extend evidence in van Binsbergen et al. (2012) and van Binsbergen, Hueskes, Koijen, and Vrugt (2013), who use dividend futures and strips

\footnotetext{
${ }^{2}$ A conditional consumption CAPM as in Lettau and Ludvigson (2001), a consumption CAPM with ultimate consumption risk as in Parker and Julliard (2005) and Malloy, Moskowitz, and Vissing-Jørgensen (2009), or downside risk as in Lettau, Maggiori, and Weber (2014) also cannot explain the duration-sorted cross section.

${ }^{3}$ Choi, Jin, and Yan (2013) provide empirical evidence consistent with the premise that institutional ownership measures short-sales constraints.
} 
with maturities of up to 10 and a sample period of 12 years. Similar to their work, I find high average returns and volatilities at the short end of the term structure, lower CAPM betas for short duration assets, and the value factor explains only part of the return difference between low and high duration stocks. I complement their work because my cross-sectional data allow me to study longer duration assets and a longer sample period. The average duration at the stock level is 19 years in my sample from 1963 to 2014 and ranges between 6 and 24 years at the portfolio level.

Exposure to untested risk factors might explain the cross section of stocks sorted on cash flow duration. Ultimately, variation in the quantity or price of risk is observationally equivalent to variation in sentiment and institutional ownership is an equilibrium outcome. My findings, however, raise the bar for novel models to be consistent with the facts I present in this paper and the puzzling findings in van Binsbergen et al. (2012) and van Binsbergen et al. (2013): why is the risk premium so high for assets with low duration, even at the very short end of the term structure?

\section{Data}

Stock return data come from the Center for Research in Security Prices (CRSP) monthly stock file. I follow standard conventions and restrict my analysis to common stocks of firms incorporated in the United States trading on NYSE, Amex, or Nasdaq. I exclude financials $(6000 \leq \mathrm{SIC}<7000)$ and utilities $(4900 \leq \mathrm{SIC}<5000)$. To account for the delisting bias in the CRSP database, I investigate the reason for the stocks' disappearance. If a company is delisted for cause (delisting codes 400-591) and has a missing delisting return, I follow the findings in Shumway (1997) and assume a return of -30\%. In some cases, CRSP reports delisting returns several months after the security stopped trading. In these instances, I pro-rate the delisting return over the intervening period as in Cohen, Polk, and Vuolteenaho (2009). Market equity (ME) is the total market capitalization at the firm level.

Balance sheet data are from the Standard and Poor's Compustat database. I define book equity (BE) as total stockholders' equity plus deferred taxes and investment tax 
credit (if available) minus the book value of preferred stock. Based on availability, I use the redemption value, liquidation value, or par value (in that order) for the book value of preferred stock. I prefer the shareholders' equity number as reported by Compustat. If these data are not available, I calculate shareholders' equity as the sum of common and preferred equity. If neither of the two are available, I define shareholders' equity as the difference between total assets and total liabilities. I supplement the book-equity data with hand-collected book-equity data from Moody's manual used in Davis, Fama, and French (2000). The book-to-market (BM) ratio of year $t$ is then the book equity for the fiscal year ending in calendar year t-1 over the market equity as of December t-1.

I define the payout ratio (PR) as net payout over net income. Net payout is the sum of ordinary dividends and net purchases of common and preferred stock. Return on equity (ROE) is the ratio of income before extraordinary items over lagged book equity. Sales growth (Sales_g) is the percentage growth rate in net sales. As for the book-to-market ratio, I calculate these numbers for the fiscal year ending in calendar t-1. Age is the number of years a firm has been in Compustat. To alleviate a potential survivorship bias due to backfilling, I require that a firm has at least two years of Compustat data.

I obtain data on institutional ownership from the Thomson Reuters 13F (TR-13F) database. These data include quarterly observations on long positions of mutual funds, hedge funds, insurance companies, banks, trusts, pension funds, and other entities with holdings of more than $\$ 100$ million of $13 \mathrm{~F}$ assets. I calculate the institutional ownership ratio (IOR) by first summing the holdings of all reporting institutions at the security level and then dividing by the total shares outstanding from CRSP. If a common stock is on CRSP but not in the TR-13F database, I assign an institutional ownership ratio of 0. I use the CRSP cumulative adjustment factor to account for stock splits and other distributions between the effective ownership date and the reporting date. The TR-13F database carries forward institutional reports up to eight quarters. In calculating the institutional ownership ratio, I only keep the holding data as they first appear in the database.

Data on analyst forecasts for earnings per share, long-term growth in earnings, and realized five-year growth in earnings come from the Institutional Brokers Estimates 
System (I/B/E/S).

The five Fama \& French factors, the momentum factor, and the one-month Treasurybill rate come from the Fama \& French data library on Ken French's webpage.

\section{A. Cash-Flow Duration}

Dur is the implied cash-flow-duration measure of Dechow, Sloan, and Soliman (2004). Dechow et al. (2004) develop this measure and show that stocks with high cash flow duration have low returns. They do not study exposure to risk factors, time variation in the slope, or the effect of short-sale constraints, but instead posit that investors in the stock market have a long holding period horizon.

Dur resembles the traditional Macaulay duration for bonds and hence reflects the weighted average time to maturity of cash flows. The ratio of discounted cash flows to price determines the weights:

$$
\operatorname{Dur}_{i, t}=\frac{\sum_{s=1}^{T} s \times C F_{i, t+s} /(1+r)^{s}}{P_{i, t}},
$$

where $D u r_{i, t}$ is the duration of firm $i$ at the end of fiscal year $t, C F_{i, t+s}$ denotes the cash flow at time $t+s, P_{i, t}$ is the current price, and $r$ is the expected return on equity. The expected return on equity is constant across both stocks and time. Allowing for firmspecific discount rates ceteris paribus amplifies cross-sectional differences in the duration measure because high-duration firms tend to have lower returns on equity (see Panel B of Table 1 and Table 2). Firm-specific discount rates, however, would not change the ordering, and hence had no effect on my later results. The relative ranking is also insensitive to changes in the level of $r .^{4}$

Contrary to bonds, stocks do not have a well-defined finite maturity, $t+T$, and cash flows are not known in advance.

Therefore, I split the duration formula into a finite detailed forecasting period and an infinite terminal value and assume the latter is paid out as level perpetuity to deal

\footnotetext{
${ }^{4}$ Variation over time in return on equity $r$ does not affect the cross-sectional ordering which is the main focus of the paper. We can interpret a constant $r$ for a given sorting year $t$ as the average return on equity over the forecasting horizon. I discuss robustness checks in Section III.
} 
with the first complication. ${ }^{5}$ This assumption allows me to write equation (1) as

$$
\operatorname{Dur}_{i, t}=\frac{\sum_{s=1}^{T} s \times C F_{i, t+s} /(1+r)^{s}}{P_{i, t}}+\left(T+\frac{1+r}{r}\right) \times \frac{P_{i, t}-\sum_{s=1}^{T} C F_{i, t+s} /(1+r)^{s}}{P_{i, t}}
$$

To tackle the second complication, I assume clean surplus accounting, start from an accounting identity, and forecast cash flows via forecasting return on equity $(R O E)$, $E_{i, t+s} / B V_{i, t+s-1}$, and growth in book equity, $\left(B V_{i, t+s}-B V_{i, t+s-1}\right) / B V_{i, t+s-1}$ :

$$
\begin{aligned}
C F_{i, t+s} & =E_{i, t+s}-\left(B V_{i, t+s}-B V_{i, t+s-1}\right) \\
& =B V_{i, t+s-1} \times\left[\frac{E_{i, t+s}}{B V_{i, t+s-1}}-\frac{B V_{i, t+s}-B V_{i, t+s-1}}{B V_{i, t+s-1}}\right] .
\end{aligned}
$$

I model returns on equity and growth in equity as autoregressive processes based on recent findings in the financial-statement analysis literature (see Dechow et al. (2004)). I estimate autoregressive parameters using the pooled CRPS-Compustat universe and assume ROE mean reverts to the average cost of equity (Nissim and Penman (2001)). Nissim and Penman (2001) also show that past sales growth is a better predictor of future growth in book equity than past growth in book equity. I assume that growth in book equity mean reverts to the average growth rate of the economy with a coefficient of mean reversion equal to average historical mean reversion in sales growth.

The book-to-market ratio and cash flow duration are often used interchangeably. A linear relationship between the book-to-market and duration exists under the assumptions that $R O E$ immediately mean reverts and that no growth occurs in the book value of equity. I will later show my measure of cash flow duration contains information over and above the book-to-market ratio.

$R O E$ has an $\mathrm{AR}(1)$ coefficient of 0.41 and $B V$ of 0.24 . I assume a discount rate $r$ of 0.12 , a steady-state average cost of equity of 0.12 , an average long-run nominal growth

\footnotetext{
${ }^{5}$ As long as the finite forecasting horizon is sufficiently long to account for extraordinary growth opportunities at the firm and industry levels, the assumption that cash flows are paid out as level annuity has no impact on my results. A potentially terminal growth rate would be constant and therefore had no impact on my cross-sectional ordering.
} 
rate of 0.06 , and a detailed forecasting period of 15 years. ${ }^{6}$ All my findings are robust to reasonable permutations of these values (see discussion in Section III).

My sample period is July 1963 until June 2014. The sample is restricted from July 1981 until June 2014 when I make use of the institutional ownership and June 1982 to June 2009 when I employ I/B/E/S data. To minimize the impact of outliers, I winsorize all variables at the $1 \%$ and $99 \%$ level.

\section{B. Descriptive Statistics}

Table 1 reports summary statistics in Panel A and cross-sectional correlations for various firm characteristics and return predictors in Panel B. I calculate all statistics annually and then average over time.

The average payoff horizon implied by stock prices is about nineteen years. An average standard deviation of five years hints at substantial cross-sectional heterogeneity in this variable. Institutions hold about $40 \%$ of all shares during my sample period, and the average firm size is $\$ 2.1$ billion.

Panel B shows that duration is strongly negatively correlated with book-to-market. ${ }^{7}$ In addition, high cash flow duration is associated with low payout rates, return-on-equity, and firm age, but high growth in sales. No linear association exists between duration and institutional ownership or size. The institutional-ownership ratio is strongly positively correlated with size.

Low-duration stocks tend to be industrial and manufacturing companies, whereas high-duration stocks were mainly in the software and internet sector in the 1990s and the bio-sciences sector in the 2000s. Table A.1 in the online appendix reports five low- and high-duration firms in 1996 and 2004.

\footnotetext{
${ }^{6}$ Variation in expected inflation could affect the expectations about the long run nominal growth rate of the economy, but should also affect the nominal discount rate. As stocks are claims on real assets, changes in inflation expectations should not affect the value of the firm. Table 5 reports results for five subsamples of ten years each. Return differences between high- and low-duration stocks are similar across different subsamples.

${ }^{7}$ Table 15 shows that my findings continue to hold within both value and growth stocks, indicating that duration has information over and above book-to-market.
} 


\section{Duration and the Term Structure of Equity Returns}

\section{A. Portfolios Sorted on Duration}

At the end of June each year t from 1963 to 2013, I sort stocks into 10 deciles based on duration for the fiscal year ending in calendar year t-1. I rebalance portfolios on an annual basis and weight returns within portfolio equally. Figure 1 plots the time-series average annual portfolio return as a function of the average median portfolio duration. This figure exhibits a negative relationship between duration and holding-period return: low-duration stocks in portfolio 1 have, on average, a one-year holding-period return of $25 \%$. The high-duration stocks in the last basket, on the contrary, earn less than $10 \%$ per annum.

I regress excess returns at the portfolio level on various risk factors to test whether traditional risk factors can explain the downward-sloping term structure of equity returns,

$$
R_{i, t}=\alpha_{i}+\sum_{s} \beta_{i, s} X_{i, s, t}+\epsilon_{i, t}
$$

where $R_{i, t}$ is excess return of portfolio $i$ at time $t, \alpha_{i}$ is a model-specific pricing error, and $\beta_{i, s}$ is the time-series loading of returns on risk factor $\mathrm{s}, X_{i, s}$, such as size.

Panel A of Table 2 presents monthly mean excess returns, OLS regression coefficients, and pricing errors for the CAPM with standard errors in parentheses for equally-weighted portfolio returns. We see in the first line of the table excess returns monotonically decrease in cash-flow duration. In contrast to the negative relationship for returns, duration is strongly positively related to CAPM betas. High-duration stocks have a CAPM beta of 1.41 compared to low-duration stocks, which have an exposure to the market of only 1.05. Decreasing returns and increasing exposure to the market result in a monotonic negative relationship between duration and pricing errors. A strategy going long low-duration stocks and shorting high-duration stocks (D1-D10 in the following) leads to a statistically significant excess return of $1.29 \%$ per month.

Panel B contains results for value-weighted returns. Size and magnitude of return 
premia are economically and statistically similar to the equally-weighted returns. The similarity between equally- and value-weighted returns is expected as size and duration are almost uncorrelated (see Table 1).

Panel $\mathrm{C}$ shows that delisting returns are not driving my results. If I do not account for delisting returns, the long-short portfolio returns is $1.03 \%$ per month compared to the baseline of $1.10 \%$ per month.

The CAPM has little explanatory power in the modern sample period (see, e.g., Campbell and Vuolteenaho (2004)). ${ }^{8}$ Table 3 reports alphas for the Fama \& French three-factor model, the three-factor model augmented with a momentum factor, and the Fama \& French five-factor model (Fama and French (2015)). The Fama \& French threefactor alpha of the D1-D10 strategy is $1.15 \%$ per month, the four-factor alpha is $0.66 \%$ per month, and the five-factor alpha is still a highly statistically significant $0.48 \%$ per month. I report factor loadings in the online appendix to conserve space (see Table A.2 to Table A.4). Stocks with high cash flow duration tend to have similar loadings on the market, size $(S M B)$, and momentum as low-duration stocks, but they have lower loadings on value $(H M L)$, profitability $(R M W)$, and investment $(C M A)$.

\section{B. Sensitivity and Subsample Analysis}

The duration measure I present in Section II depends on assumptions regarding the persistence in ROE and sales growth, the long-run growth rate in sales and ROE, the discount rate, and the detailed forecasting horizon. Figure 2 reports excess returns of a long-short portfolio for 11 different values of each parameter. Specifically, the discount rate ranges between 0.07 and 0.17 (baseline 0.12 ), the detailed forecast horizon between 10 and 20 years (baseline 15), the sales growth persistence between 0.09 and 0.36 (baseline 0.2411), the ROE persistence between 0.15 and 0.65 (baseline 0.4067 ), the steady-state growth rate in sales between 0.01 and 0.11 (baseline 0.06), and the steady-state growth rate in ROE between 0.07 and 0.17 (baseline 0.12 ).

The red line in each panel shows the excess return for the baseline parameter values.

\footnotetext{
${ }^{8}$ One exception is the cross section of stocks sorted on price stickiness (see Weber (2015) and Gorodnichenko and Weber (2016)). Price stickiness and cash flow duration are uncorrelated in my sample.
} 
We see in the top panels of Figure 2 assumptions regarding the discount rate or the detailed forecasting horizon barely affect the slope of the term structure of equity returns.

In the middle panels, we see moving from a sales growth persistence of 0.09 to a persistence of 0.36 increases the cross-sectional returns premium from $1.01 \%$ to $1.24 \%$ per month, whereas increasing the persistence in ROE lowers the return premium from $1.30 \%$ to $0.62 \%$.

In the bottom panels, we see the cross-sectional return premium is most sensitive to extreme assumptions regarding the long-run sales growth and ROE. Increasing the long-run nominal growth rate of the economy from a baseline of $6 \%$ to $11 \%$ cuts the duration premium in half. Decreasing the long-run ROE from $12 \%$ to $7 \%$ instead lowers the excess return by a similar amount.

Table 4 reports excess returns at the portfolio level for economically reasonable variations of parameter values. Overall, over a wide range of parameter values, we find an economically large and statistically significant downward-sloping term structure of equity returns. The duration premium seems a pervasive feature of the data which alleviates concerns of estimation uncertainty driving the results.

\section{Time Variation}

The predictive power of many return characteristics varies over time. Recent examples are the disappearance of the size premium or the momentum crash (see Daniel and Moskowitz (2016)).

Table 5 reports average monthly excess returns at the portfolio level decade by decade. Across decades, we see an average monthly duration premium of more than $1 \%$ per month. The only exception is the very first decade from 1963 to 1973, during which the difference in returns between low- and high-duration stocks is merely $0.69 \%$ per month, which is still economically large and statistically significant.

The term structure of interest rates often inverts during adverse macroeconomics periods. Ait-Sahalia, Karaman, and Mancini (2015) show that the term structure of risk premia is downward-sloping during recessions, but flat or upward-sloping during normal times. Figure 3 is a time series plot of annual excess returns for the low minus high 
duration portfolio (blue line) and the market excess return (red dash-dotted line). Both excess returns show substantial variation over time. During stock market downturns in the earlier part of the sample up to 2001, we also see in the cross section of equity returns a more pronounced downward-sloping pattern resulting in a large duration premium. During the recent financial crisis, instead, low-duration stock fell more than high-duration stocks, and we observe an upward-sloping term structure of equity returns and a negative duration premium. The two time series have a negative correlation of $-29.17 \%$, which increases in absolute value to $-36.33 \%$ when the sample ends in June 2007.

There is substantial variation over time in the duration premium. Over longer periods, such as decades, there is a robustly positive downward-sloping term structure of equity returns. The downward slope was steepest during times of low market returns in the earlier part of the sample, but we observe an upward-sloping term structure during the onset of the recent financial crisis. The market return fell sharply, as did the duration premium.

\section{Variation with Investor Sentiment}

The results so far show that exposure to traditional risk factors does not suffice to explain the lower returns of high-duration stocks compared to low-duration stocks. I now investigate a potential mispricing explanation for this finding. I present Fama \& French three-factor adjusted monthly excess returns following periods of high and low investor sentiment. Stambaugh et al. (2012) argue that anomalies should be stronger following periods of high investor sentiment if mispricing is at the root of the anomaly. ${ }^{9}$ In periods of high investor sentiment, the views of investors about the prospects of many stocks could be overly optimistic, leading to temporal overpricing. This effect should be strongest for stocks that are hard to value. A positive return to the D1-D10 strategy should be larger after periods of overpricing and be mainly attributable to the short leg. ${ }^{10}$

The mean level of the sentiment index of Baker and Wurgler (2006) determines

\footnotetext{
${ }^{9}$ Stambaugh, Yu, and Yuan (2015) show that investor sentiment and arbitrage asymmetry can also explain the idiosyncratic volatility puzzle (see Ang, Hodrick, Xing, and Zhang (2006)).

${ }^{10}$ High-duration firms tend to be younger firms with negative payout ratios and returns on equity, but historically strong growth in sales, and are therefore potentially difficult to value (see Table 1).
} 
periods of high and low investor sentiment. Following Stambaugh et al. (2012), I define a high-sentiment month as one in which the sentiment index was above the mean value in the previous month.

Table 6 presents Fama \& French-adjusted excess returns following periods of high and low investor sentiment in Panel A. The benchmark-adjusted excess returns conditional on high and low sentiment are the estimates of $\alpha_{H}$ and $\alpha_{L}$ in the following equation:

$$
R_{i, t}=\alpha_{i, H} d_{H, t}+\alpha_{i, L} d_{L, t}+\beta_{\text {Market }} \text { Market }_{t}+\beta_{S M B} S M B_{t}+\beta_{H M L} H M L_{t}+\epsilon_{i, t},
$$

where $d_{H, t}$ and $d_{L, t}$ are dummies indicating high- and low-investor-sentiment months.

A strong negative relationship exists between duration and Fama \& French-adjusted excess returns in high-sentiment months: the D1-D10 strategy earns a highly statistically significant abnormal return of $1.32 \%$ per month. Looking at the numbers for the individual portfolios, we see almost $90 \%$ of this abnormal return is due to the large negative riskadjusted return for the high-duration portfolio. The profitability of the D1-D10 strategy is reduced by a factor of 3 to $0.46 \%$ in low-sentiment months.

Comparing the results within portfolios across high- and low-sentiment months indicates high-duration stocks could be prone to overpricing in periods of high investor sentiment. High-duration stocks earn negative risk-adjusted returns after periods of high sentiment. No abnormal returns occurs in either direction following periods of low sentiment for high-duration stocks.

Panel $\mathrm{B}$ of Table 6 measures the relationship of changes in the sentiment index and abnormal portfolio returns. I run separate time-series regressions for each of the 10 portfolios of Fama \& French-adjusted returns on changes in the sentiment index. I find that low- and intermediate-duration portfolios show no significant relationship, whereas high-duration portfolios load strongly on changes in the sentiment index. This evidence lends further support to temporary overpricing of high-duration stocks. 


\section{E. Analyst Expectations}

Table 7 reports historical cash-flow fundamentals and analyst forecasts. ${ }^{11}$ Panel A presents the evolution of the average portfolio long-term earnings growth (LTG) forecast from June of year $\mathrm{t}$ until June of year $\mathrm{t}+4$. LTG is a forecast of the growth rate in earnings per share before extraordinary items over the next three to five years. LTG for year t increases monotonically in duration from $13 \%$ for low-duration stocks to about $26 \%$ for portfolio D10. This forecast remains fairly stable for low-duration stocks as we look at years $t+1$ until $t+4$. On the contrary, for high duration-stocks, LTG falls by $7 \%$ over the next four years. $^{12}$

The drop in expected long-term growth of high-duration stocks could be due to overly optimistic initial forecasts or mean reversion in earnings. To discriminate between these two explanations, I report realized five-year growth in earnings between years $t-6$ to $t-1$ and $t$ to $t+5$ in Panel B. For the pre-portfolio-formation period, we see again a strong positive association between realized five-year growth in earnings and duration. Low-duration stocks grow on average by $7 \%$, whereas high-duration stocks grow by $31 \%$. This difference in growth rates disappears over the following five years; both high- and low-duration stocks grow at an annual rate of roughly $10 \%$ per annum. This finding hints at an extrapolation bias in analyst forecasts for the long-term growth prospects of high-duration firms and further indicates that market participants are overly optimistic in their perceptions of the prospects of high-duration stocks.

Panel C corroborates this finding looking at three different measures of standardized earnings surprises following Livnat and Mendenhall (2006). ${ }^{13} S U E 1$ uses a rolling seasonal random walk model for expected earnings, $S U E 2$ excludes special items, and $S U E 3$ uses IBES-reported analyst forecasts and actuals. Stocks with low cash flow duration have a positive median earnings surprise across all three measures. High-duration stocks, on the other hand, have negative or 0 median earnings surprises. Research in accounting

\footnotetext{
${ }^{11}$ Analysts mainly cover large companies, and therefore the following results might not be representative for the universe of CRPS/Compustat stocks considered so far. In untabulated results, I also find a downward-sloping term structure of equity returns for the subset of IBES firms.

${ }^{12}$ I report results for all firms with non-missing LTG forecasts for all periods. Results are unchanged if I look at all firms with non-missing forecasts at any point in time.

${ }^{13}$ See also Birru (2015). I thank Justin Birru for suggesting this test.
} 
associates earnings that just meet analyst forecasts with earnings management (see Skinner and Sloan (2002) and Burgstahler and Eames (2006)).

\section{Short-Sale Constraints and the Term Structure of Equity Returns}

The previous section illustrates that overpricing could be at the core of a downward-sloping term structure of equity returns. For overpricing to persist temporarily, however, rational arbitrageurs have to be restrained from taking sufficiently large short positions to correct the mispricing (see Miller (1977)).

In this section, I investigate whether the low returns of high-duration stocks are concentrated among short-sale-constrained stocks as proxied by low institutional ownership. I first verbally describe the testable implications. I then motivate institutional ownership as a proxy for short-sale constraints, and analyze the interplay of duration and short-sale constraints. I close this section by briefly discussing the robustness of my results.

\section{A. Hypotheses}

Hypothesis 1 The positive abnormal return of going long low-duration stocks and short high-duration stocks (D1-D5 in the following) should be contained in portfolios with low institutional ownership.

Hypothesis 1 is a direct implication of the Miller (1977) theory. Divergence of opinion about the future prospects of difficult-to-value, high-duration stocks paired with shortsale constraints leads first to overpricing and then to low returns once the mispricing is corrected. If the downward-sloping term structure of equity returns is due to mispricing, the negative relationship between duration and returns should become weaker with less binding short-sale constraints.

Hypothesis 2 High-duration portfolios should drive the differences in returns of the D1D5 strategy across categories of institutional ownership. 
Hypothesis 2 follows from the fact that short-sale constraints allow for overpricing, but not for underpricing. If a specific stock is underpriced, sophisticated investors can take sufficiently large long positions independent of short-sale constraints. Furthermore, shortduration stocks pay off most of their cash flows in the near-term future, have high returns on equity and low growth in sales, and are therefore unlikely candidates for overpricing.

\section{B. Institutional Ownership and Short-Sale Constraints}

Institutional and cultural considerations potentially restrict short-sale activities of institutional investors. Almazan, Brown, Carlson, and Chapman (2004) report that charters restrict about $70 \%$ of mutual funds to pursue any short-selling activities, and only $2 \%$ actually do sell short. Restricted institutions also do not synthetically engineer short positions. Koski and Pontiff (1999) report that only $21 \%$ of equity mutual funds make use of any derivative instruments. Therefore, the only possibility for institutions to express negative opinions about the outlook of specific stocks is to reduce existing long positions. Once institutions have sold their positions completely, they have to sit on the sidelines and their negative opinions are no longer reflected in market prices. A direct implication of these arguments is arbitrage capital increases in institutional ownership.

Contrary to the centralized market for shorting NYSE stocks in the early $20^{\text {th }}$ century, nowadays short sellers have to search for a stock lender in opaque shorting markets. A lower level of stock loan supply therefore implies tighter short-sale constraints due to higher search cost (see Duffie, Gârleanu, and Pedersen (2002)). D'Avolio (2002) shows institutional ownership is the most important cross-sectional determinant of stock loan supply. He also reports that custody banks that engage in stock lending on behalf of their institutional clients are the most reliable stock lenders, whereas discount brokers are the least dependable.

Short sellers could also have a preference for borrowing stocks from institutional owners. Dechow, Hutton, Meulbroek, and Sloan (2001) highlight that short squeezes, the recall of stock loans by lenders, are less likely for stocks with high institutional ownership. In addition, transaction and borrowing costs also decrease in institutional ownership.

These arguments indicate that short-sale constraints are tighter and the cost of 
shorting is higher for stocks with low institutional ownership.

Institutional ownership is of course an endogenous variable. Institutional ownership has increased substantially over my sample period which, ceteris paribus, should have increased the stock loan supply and lowered short-selling costs. ETFs and index funds drove a large part of the increase in institutional ownership in recent years. My crosssectional prediction should continue to hold, however, as cash-flow duration and index inclusion are almost orthogonal. These passive institutions also just replicate an index and are therefore not actively trading against potential mispricings of stocks.

Stock-lending fees are an alternative measure for short-sale constraints (see Drechsler and Drechsler (2014)). Equity lending data are, however, not available before 2004, as opposed to data on institutional ownership, which start in 1980.

\section{Descriptive Statistics}

Table 1 illustrates that institutional ownership and size are strongly positively correlated. Many return anomalies are stronger within smaller stocks, potentially because of lower liquidity and higher transaction costs (Griffin and Lemmon (2002) and Israel and Moskowitz (2013)). I follow Nagel (2005) to purify my proxy for short-sale constraints from confounding size effects, and sort on residual institutional ownership. ${ }^{14}$ In each sorting year, I run a cross-sectional regression of logit-transformed institutional ownership on a constant, the natural $\log$ arithm of size, $\log (M E)$, as well as $\log$ size squared and use the residual, $R I O R_{i t}$, of this regression as my sorting variable:

$$
\log \frac{I O R_{i t}}{1-I O R_{i t}}=\alpha+\beta_{1} \log (M E)+\beta_{2}(\log (M E))^{2}+R I O R_{i t}
$$

I replace institutional ownership ratios below 0.0001 and above 0.9999 with these threshold values. In addition, I also delete the $20 \%$ smallest stocks from my sample. ${ }^{15}$

\footnotetext{
${ }^{14}$ Wang (2014) and Stambaugh et al. (2015), among many other papers, also use residual institutional ownership as a proxy for short-sale constraints.

${ }^{15}$ Jones and Lamont (2002) point out that controlling for confounding size effect can be crucial to disentangle the cost of short selling from size effects. Excluding the quintile of the smallest stocks also ensures my findings are not driven by stock-picking skills of institutions. Lewellen (2011) shows that institutions in the aggregate have little stock-picking skills, and institutional ownership has no predictive power for returns. For micro caps, however, he finds a quarterly abnormal return of $0.57 \%$.
} 
Table 8 provides time-series averages of annual cross-sectional means of firm characteristics for the 25 portfolios sorted on duration and residual institutional ownership. At the end of June each year t from 1981 to 2013, I sort all common stocks listed on NYSE, AMEX, and NASDAQ above the 20\% size percentile into quintiles based on duration for all firms with fiscal years ending in calendar year t-1. I intersect these quintiles with an independent sort on residual institutional ownership as of December t-1. Using a six-month time lag for institutional ownership ensures that short-term outperformance of institutional trades do not drive my results (see Chen et al. (2000)).

Panel A shows low-duration stocks in portfolio D1 have on average a duration of about 11 years, whereas high-duration firms have an average duration of roughly 25 years. Duration within duration sorts, on the other hand, is constant across residual institutional ownership classes. Panel B captures the negative correlation between duration and book-to-market, and suggests that institutions tend to hold stocks with higher book-to-market ratios. Panel $\mathrm{C}$ verifies that institutional ownership is quite homogeneous within the residual institutional ownership category, but varies substantially with residual institutional ownership. According to Panels D and E, high-duration stocks have lower or even negative payout ratios and returns-on-equity, whereas no strong relationship with residual institutional ownership exists. Across portfolios of residual institutional ownership, high-duration stocks have higher sales growth and tend to be younger than low-duration stocks (Panels F and G). Sales growth and the number of years a firm has been on Compustat is fairly stable within portfolios of the same duration. As for size in Panel G, I find an inverse U-shaped relationship with residual institutional ownership similar to Nagel (2005). However, compared to the variation of size in the CRSP universe, the variation of size across sorts on residual ownership is negligible. The sorting on residual ownership is therefore successful in engineering variation in my short-sale-constraints proxy, independent of size.

Overall, the double sorting generates portfolios that are fairly similar across residual institutional ownership portfolios, whereas they exhibit large variation across duration categories. High-duration stocks tend to have characteristics that Baker and Wurgler (2006) and Griffin and Lemmon (2002) associate with speculative, hard-to-value stocks 
that are prone to divergence of opinion. Daniel et al. (1998) draw on the insights from the psychology literature (see, e.g., Einhorn (1980)) and argue mispricing should be stronger for stocks requiring more judgement in valuing them and for which feedback on this evaluation is ambiguous in the short run. They mention as an example stocks for which the bulk of cash flows is expected to be paid out far ahead in the future. In the next subsection, I test whether short-sale constraints keep smart money out of the market so that market prices temporarily reflect only the opinions of the most optimistic investors, leading first to overpricing and then to negative abnormal returns once this overpricing is corrected.

\section{Effect of Short-Sale Constraints on the Term Structure of Equity Returns}

Table 9 reports monthly mean excess returns for the 25 portfolios. We see a pronounced downward-sloping term structure of equity returns for stocks with low residual institutional ownership, which are potentially the most short sale constrained. Low-duration stocks earn an excess return of $1.02 \%$ per month. The return decreases monotonically in duration. High-duration stocks earn an excess return of $-0.30 \%$ per month. The spread in excess returns for the two extreme-duration portfolios is $1.32 \%$ per month and highly statistically significant. ${ }^{16}$

Focusing on the long-short portfolio in the last column, we see excess returns decrease monotonically in residual institutional ownership. For stocks that are potentially the least short-sale constrained, the long-short portfolio has a statistically insignificant excess return of $0.15 \%$ per month, confirming Hypothesis 1 . The difference in returns across residual institutional ownership portfolios of more than $1 \%$ per month comes entirely from variation in returns for high-duration stocks. Excess returns increase from $-0.30 \%$ to $0.94 \%$ from low to high residual institutional ownership, as predicted by Hypothesis 2 . Low-duration stocks, on the other hand, exhibit no variation with the proxy of short-sale constraints. Institutional ownership only matters for stocks that are potentially prone

\footnotetext{
${ }^{16}$ The results in Table 9 do not directly map into the results of Table 2 as stocks have to be above the $20 \%$ size percentile and the sample starts in 1981 rather than 1963.
} 
to differences in opinion. A strategy going long the low-residual institutional ownership portfolio and short the high-residual institutional ownership portfolio (I1 - I5) earns an insignificant excess return of $-0.08 \%$ for stocks with low cash flow duration. This spread decreases monotonically to a highly significant $-1.24 \%$ per month for high-duration stocks. This finding is in line with the prediction of the Miller (1977) theory. Differences in opinion paired with short-sale constraints lead to temporal overpricing. High-duration, short-sale constrained stocks earn low returns once the overpricing is corrected. The data do not back the alternative hypothesis that institutional ownership reflects smart money. Returns increase in residual institutional ownership only for stocks within the highest duration categories. ${ }^{17}$

Stocks with similar duration but different degrees of residual institutional ownership have similar fundamentals (see Table 8). Therefore, it is unlikely that specific investment styles or superior analysis and information of institutions drive the heterogeneous effect of institutional ownership across duration categories. Nevertheless, I correct for the portfolios' exposure to risk in the following to rule out covariances with risk factors explain the pattern in excess returns presented in Table $9 .^{18}$

Correcting for market exposure does not materially change any of the previous findings for excess returns. Table 10 shows that the D1-D5 strategy earns a risk-adjusted excess return of $1.61 \%$ per month for stocks with low institutional ownership. This differential decreases to a statistically insignificant $0.40 \%$ for stocks that are potentially the least short sale constrained.

The CAPM has little explanatory power after 1963. Adjusting for exposure to the three Fama \& French risk factors has no significant impact on pricing errors. We see in Table 11 that the abnormal excess returns of the long-short portfolio decrease monotonically in institutional ownership, resulting in a spread across institutional ownership categories of $1.22 \%$ per month. This spread is even slightly larger than the

\footnotetext{
${ }^{17}$ Another alternative is that short-sale constraints are also more binding for high-duration stocks. Diether, Lee, and Werner (2009), however, show that short-selling activity is higher for growth stocks.

${ }^{18}$ Lewellen (2011) shows that even though institutions as a whole have no stock-picking skills for large stocks, different types of institutions have modest ability compared to the CAPM. Controlling for book-to-market and momentum, however, subsumes this effect.
} 
spread in raw or CAPM-adjusted excess returns. ${ }^{19}$ Adjusting as well for momentum reduces pricing errors for high-duration stocks, while having minor impacts for other categories. The D1-D5 abnormal return is reduced to a highly significant $0.94 \%$ per month within the class of low residual institutional ownership stocks. For the least short-sale-constrained stocks, this differential abnormal return is $-0.10 \%$ per month and statistically indistinguishable from zero. Table 13 reports five-factor alphas. The difference in alphas of the long-short portfolios between high- and low-duration stocks is again more than $1 \%$ per month and highly statistically significant.

Tables A.6 to A.10 report the factor loadings for the 25 portfolios. CAPM betas increase from about 1 for low-duration stocks to about 1.45 for high-duration stocks. This pattern is independent of institutional ownership. For the Fama \& French three-factor model, high-duration stocks have higher exposure to market risk and load stronger on size $(S M B)$, but show less common variation with vale $(H M L)$. Again, factor loadings are remarkably similar across categories of residual institutional ownership. High-duration stocks also tend to load more negatively on momentum. The difference in exposure to market risk and size $(S M B)$ for high- versus low-duration stocks vanishes for the five-factor model. High-duration stocks tend to load more negatively on value $(H M L)$, profitability $(R M W)$, and investment $(C W A)$.

My results are consistent with a mispricing explanation for the negative crosssectional relationship between cash flow duration and stock returns in the cross section: the interplay between short-sale constraints and differences in opinion is what seems responsible for a large part of the empirical regularity that high-duration stocks earn lower returns compared to low-duration stocks. Exposure to untested risk factors might, however, explain the cross section of stocks sorted on cash flow duration. Independent of my findings, the puzzle of van Binsbergen et al. (2012) and van Binsbergen et al. (2013) remains: why do very short-term assets have such a high risk premium?

\footnotetext{
${ }^{19}$ Nevertheless, differences in mean excess returns compared to differences in factor loadings largely drive the effect.
} 


\section{E. Robustness}

I perform several robustness checks to corroborate my previous results and distinguish them from findings in the literature. Table 14 contains Fama-French-adjusted pricing errors conditional on size. I first sort all stocks into two bins based on market capitalization. Within each size bin, I then sort firms into tertiles based on duration, which I then intersect with an independent sort on residual institutional ownership. Panel I reports Fama-French alphas for small stocks, whereas Panel II contains alphas for large stocks. For both small and large stocks, we see a pronounced downward-sloping term structure of equity returns for the lowest residual institutional ownership portfolios. The differential in abnormal returns between high- and low-duration stocks is $1.45 \%$ per month for small stocks and $0.72 \%$ for large stocks. This differential abnormal return again decreases in residual institutional ownership, leaving a highly significant spread of $1.52 \%$ between high- and low-residual institutional ownership categories for small stocks and $0.52 \%$ for large stocks.

Table 15 reports results for a similar exercise with book-to-market as a conditioning variable. The previous findings hold both for growth stocks in Panel I and value stocks in Panel II. A negative relation between duration and returns only exists for the most constrained portfolios.

\section{Conclusion}

I construct a measure of cash flow duration at the firm level using financial statement data. Portfolios of stocks sorted into deciles based on the measure of cash flow duration exhibit a spread in returns between low- and high-duration stocks of more than $1 \%$ per month. Low-duration stocks have a monthly mean excess return of $1.45 \%$, whereas high-duration stocks earn $0.32 \%$ per month. Exposure to classical risk factors cannot explain this pattern in returns. A portfolio long low-duration stocks and short high-duration stocks earns a statistically significant five-factor alpha of $0.48 \%$ per month. The return of this arbitrage portfolio varies substantially with investor sentiment. It is three times higher after periods of high investor sentiment. 
The variation in the return differential with investor sentiment indicates that mispricing could explain the downward-sloping term structure of equity returns. I study the earnings expectations of market participants and find that (a) analysts have overly optimistic growth forecasts in fundamentals for high-duration stocks, which they adjust downwards over time; (b) analysts extrapolate from past earnings growth into the future; and (c) high-duration stocks have negative earnings surprises and seem to engage in earnings management.

Mispricing can only persist in the presence of limits to arbitrage. I provide evidence that the interplay between differences of opinion and short-sale constraints drives my results. Within short-sale-constrained stocks, I find a statistically and economically large spread in excess returns between high- and low-duration stocks of more $1.32 \%$ per month. On the contrary, no difference in returns occurs across duration categories for unconstrained stocks, consistent with models of rare disaster (Barro (2006) and Gabaix (2012)).

In line with my proposed explanation for the empirical facts, returns do not vary with short-sale constraints for short-duration stocks. Any variation in returns is driven by high-duration portfolios, which exhibit a spread in excess returns across categories of short-sale constraints of more than $1 \%$ per month without differing in firm characteristics or exposure to risk factors.

Although correcting for standard risk factors has no impact on any of these conclusions, exposure to other risk factors might still explain the negative relation between cash flow duration and returns. Variation in the quantity or price of risk is observationally equivalent to variation in investor sentiment.

My findings complement and extend evidence in van Binsbergen et al. (2012) and van Binsbergen, Hueskes, Koijen, and Vrugt (2013). These papers use clean measures of duration, but the dividend strips and futures data they use limit their analysis to a short sample and assets with duration of only up to 10 years. Using information in the cross section of stock returns, I am able to study a large time series and assets with duration of more than 25 years. 


\section{References}

Ai, H., M. Croce, A. Diercks, and K. Li (2012). Production-based term structure of equity returns. Unpublished manuscript, University of Minnesota.

Ait-Sahalia, Y., M. Karaman, and L. Mancini (2015). The term structure of variance swaps and risk premia. Unpublished manuscript, Princeton University.

Almazan, A., K. Brown, M. Carlson, and D. Chapman (2004). Why constrain your mutual fund manager? Journal of Financial Economics 73(2), 289-321.

Ang, A., R. J. Hodrick, Y. Xing, and X. Zhang (2006). The cross-section of volatility and expected returns. The Journal of Finance 61(1), 259-299.

Baker, M. and J. Wurgler (2006). Investor sentiment and the cross-section of stock returns. The Journal of Finance 61 (4), 1645-1680.

Bansal, R. and A. Yaron (2004). Risks for the long run: A potential resolution of asset pricing puzzles. Journal of Finance 59(4), 1481-1509.

Barro, R. J. (2006). Rare disasters and asset markets in the twentieth century. The Quarterly Journal of Economics 121(3), 823-866.

Belo, F., P. Collin-Dufresne, and R. S. Goldstein (2015). Dividend dynamics and the term structure of dividend strips. The Journal of Finance 70(3), 1115-1160.

Birru, J. (2015). Psychological barriers, expectational errors, and underreaction to news. Unpublished manuscript, Ohio State University.

Boguth, O., M. Carlson, A. J. Fisher, and M. Simutin (2012). Leverage and the limits of arbitrage pricing: Implications for dividend strips and the term structure of equity risk premia. Unpublished manuscript, UBC.

Burgstahler, D. and M. Eames (2006). Management of earnings and analysts' forecasts to achieve zero and small positive earnings surprises. Journal of Business Finance \& Accounting 33(5-6), 633-652.

Campbell, J. and J. Cochrane (1999). By force of habit: a consumption-based explanation of aggregate stock market behavior. Journal of Political Economy 107(2), 205-251.

Campbell, J. Y. and T. Vuolteenaho (2004). Bad beta, good beta. The American Economic Review 94(5), 1249-1275.

Chen, H.-L., N. Jegadeesh, and R. Wermers (2000). The value of active mutual fund management: An examination of the stockholdings and trades of fund managers. The Journal of Financial and Quantitative Analysis 35(3), 343-368.

Choi, J., L. Jin, and H. Yan (2013). What does stock ownership breadth measure? Review of Finance 17(4), 1239-1278.

Cohen, R. B., C. Polk, and T. Vuolteenaho (2009). The price is (almost) right. The Journal of Finance 64 (6), 2739-2782.

Corhay, A., H. Kung, and L. Schmid (2015). Competition, markups and predictable returns. Unpublished manuscript, LBS.

Croce, M., M. Lettau, and S. Ludvigson (2015). Investor information, long-run risk, and the term structure of equity. The Review of Financial Studies 28(3), 706-742.

Daniel, K., D. Hirshleifer, and A. Subrahmanyam (1998). Investor psychology and security market under- and overreactions. The Journal of Finance 53(6), 1839-1885. 
Daniel, K. D. and T. J. Moskowitz (2016). Momentum crashes. Journal of Financial Economics (forthcoming).

Davis, J. L., E. F. Fama, and K. R. French (2000). Characteristics, covariances, and average returns: 1929 to 1997. The Journal of Finance 55(1), 389-406.

D'Avolio, G. (2002). The market for borrowing stock. Journal of Financial Economics 66(2), 271-306.

Dechow, P., A. Hutton, L. Meulbroek, and R. Sloan (2001). Short-sellers, fundamental analysis, and stock returns. Journal of Financial Economics 61(1), 77-106.

Dechow, P., R. Sloan, and M. Soliman (2004). Implied equity duration: A new measure of equity risk. Review of Accounting Studies 9(2-3), 197-228.

Diether, K. B., K.-H. Lee, and I. M. Werner (2009). Short-sale strategies and return predictability. Review of Financial Studies 22(2), 575-607.

Drechsler, I. and Q. F. Drechsler (2014). The shorting premium and asset pricing anomalies. Unpublished manuscript, New York University.

Duffie, D., N. Gârleanu, and L. Pedersen (2002). Securities lending, shorting, and pricing. Journal of Financial Economics 66(2), 307-339.

Einhorn, H. (1980). Overconfidence in judgment. New Directions for Methodology of Social and Behavioral Science 4 (1), 1-16.

Fama, E. F. and K. R. French (2015). A five-factor asset pricing model. Journal of Financial Economics 116(1), 1-22.

Favilukis, J. and X. Lin (2016). Wage rigidity: A solution to several asset pricing puzzles. The Review of Financial Studies 29(1), 148-192.

Gabaix, X. (2012). Variable rare disasters: An exactly solved framework for ten puzzles in macro-finance. Quarterly Journal of Economics 127(2), 645-700.

Gorodnichenko, Y. and M. Weber (2016). Are sticky prices costly? Evidence from the stock market. American Economic Review 106(1), 165-199.

Griffin, J. M. and M. L. Lemmon (2002). Book-to-market equity, distress risk, and stock returns. The Journal of Finance 57(5), 2317-2336.

Israel, R. and T. Moskowitz (2013). The role of shorting, firm size, and time on market anomalies. Journal of Financial Economics 108(2), 275-301.

Jones, C. and O. Lamont (2002). Short-sale constraints and stock returns. Journal of Financial Economics 66(2-3), 207-239.

Koski, J. and J. Pontiff (1999). How are derivatives used? Evidence from the mutual fund industry. The Journal of Finance 54 (2), 791-816.

Lettau, M. and S. Ludvigson (2001). Resurrecting the (C) CAPM: a cross-sectional test when risk premia are time-varying. Journal of Political Economy 109(6), 1238-1287.

Lettau, M., M. Maggiori, and M. Weber (2014). Conditional risk premia in currency markets and other asset classes. Journal of Financial Economics 114 (2), 197-225.

Lettau, M. and J. A. Wachter (2007). Why is long-horizon equity less risky? A durationbased explanation of the value premium. The Journal of Finance 62 (1), 55-92.

Lewellen, J. (2011). Institutional investors and the limits of arbitrage. Journal of Financial Economics 102(1), 62-80.

Livnat, J. and R. R. Mendenhall (2006). Comparing the post-earnings announcement drift 
for surprises calculated from analyst and time series forecasts. Journal of Accounting Research 44(1), 177-205.

Lopez, P., D. Lopez-Salido, and F. Vazquez-Grande (2015). Nominal rigidities and the term structures of equity and bond returns. Technical report, Unpublished manuscript, FED Board.

Malloy, C., T. Moskowitz, and A. Vissing-Jørgensen (2009). Long-run stockholder consumption risk and asset returns. The Journal of Finance 64(6), 2427-2479.

Marfè, R. (2016). Income insurance and the equilibrium term-structure of equity. Journal of Finance (forthcoming).

Miller, E. M. (1977). Risk, uncertainty, and divergence of opinion. The Journal of Finance 32(4), 1151-1168.

Nagel, S. (2005). Short sales, institutional investors and the cross-section of stock returns. Journal of Financial Economics 78(2), 277-309.

Nissim, D. and S. Penman (2001). Ratio analysis and equity valuation: From research to practice. Review of Accounting Studies 6(1), 109-154.

Parker, J. and C. Julliard (2005). Consumption risk and the cross section of expected returns. Journal of Political Economy 113(1), 185-222.

Schulz, F. (2015). On the timing and pricing of dividends: Revisiting the term structure of the equity risk premium. Technical report, Unpublished manuscript, University of Washington.

Shumway, T. (1997). The delisting bias in CRSP data. The Journal of Finance 52(1), $327-340$.

Skinner, D. J. and R. G. Sloan (2002). Earnings surprises, growth expectations, and stock returns or don't let an earnings torpedo sink your portfolio. Review of Accounting Studies 7(2-3), 289-312.

Stambaugh, R. F., J. Yu, and Y. Yuan (2012). The short of it: Investor sentiment and anomalies. Journal of Financial Economics 104(2), 288-302.

Stambaugh, R. F., J. Yu, and Y. Yuan (2015). Arbitrage asymmetry and the idiosyncratic volatility puzzle. The Journal of Finance 70 (5), 1903-1948.

van Binsbergen, J., M. Brandt, and R. Koijen (2012). On the timing and pricing of dividends. American Economic Review 102(4), 1596-1618.

van Binsbergen, J., W. Hueskes, R. Koijen, and E. Vrugt (2013). Equity yields. Journal of Financial Economics 110(3), 503-519.

van Binsbergen, J. H. and R. S. Koijen (2015). The term structure of returns: Facts and theory. Unpublished manuscript, Wharton.

Wang, C. (2014). Institutional holding, low beta and idiosyncratic volatility anomalies. Unpublished manuscript, Yale SOM.

Weber, M. (2015). Nominal rigidities and asset pricing. Unpublished manuscript, University of Chicago. 
Figure 1: Average Term Structure of Equity

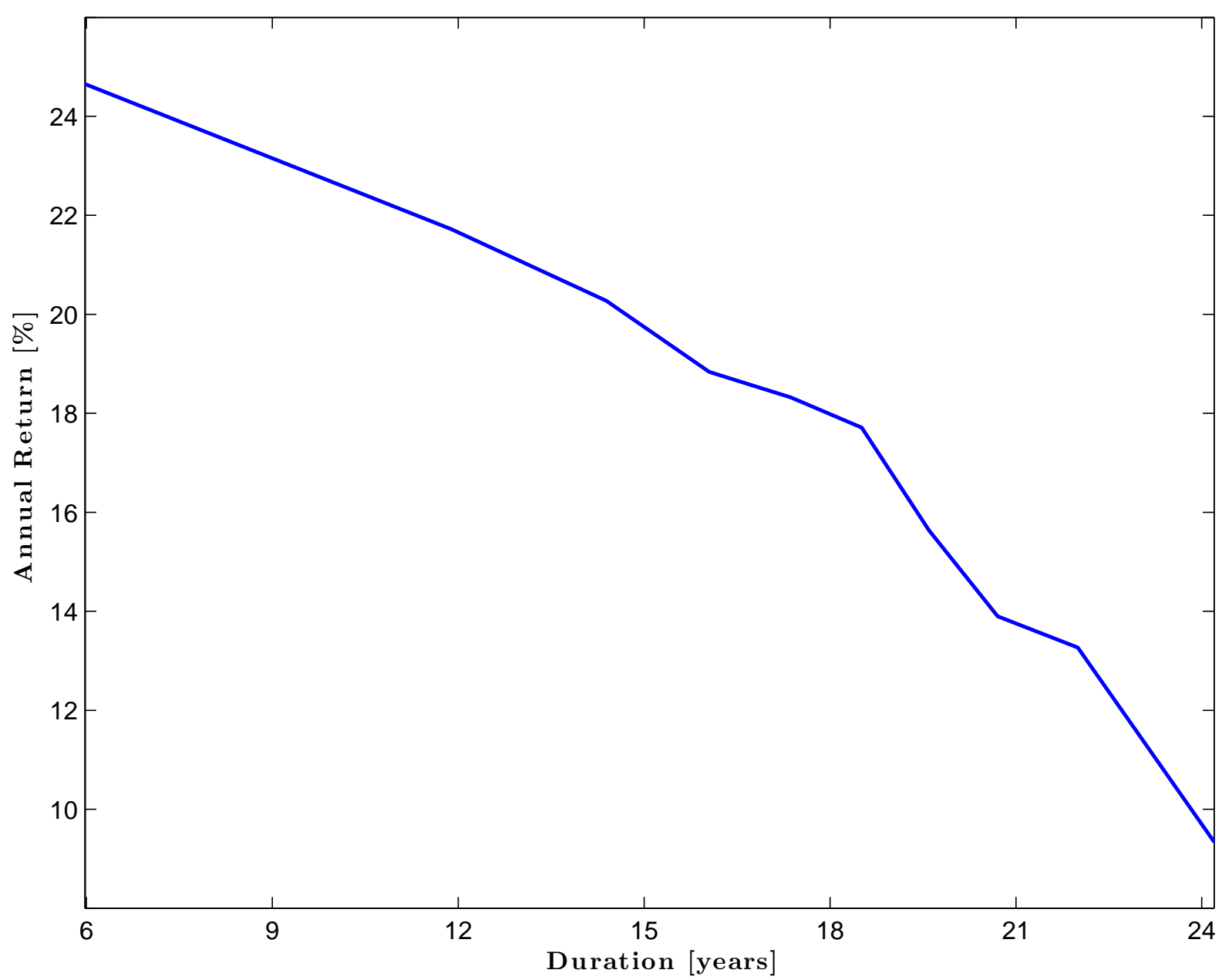

This figure plots the time series average annual portfolio return as a function of the average median portfolio cash flow duration. I sort all common stocks listed on NYSE, AMEX, and NASDAQ at the end of June each year $t$ from 1963 to 2013 into deciles based on duration for all firms with fiscal years ending in year t-1. I weight returns equally and include delisting returns. If a firm is delisted for cause (delisting code between 400 and 591) and has missing delisting return, I assume a delisting return of -30\% following Shumway (1997). Financial statement data come from Compustat. For missing Compustat book equity values, I use the Moody's book equity information collected by Davis et al. (2000). 
Figure 2: Sensitivity Analysis

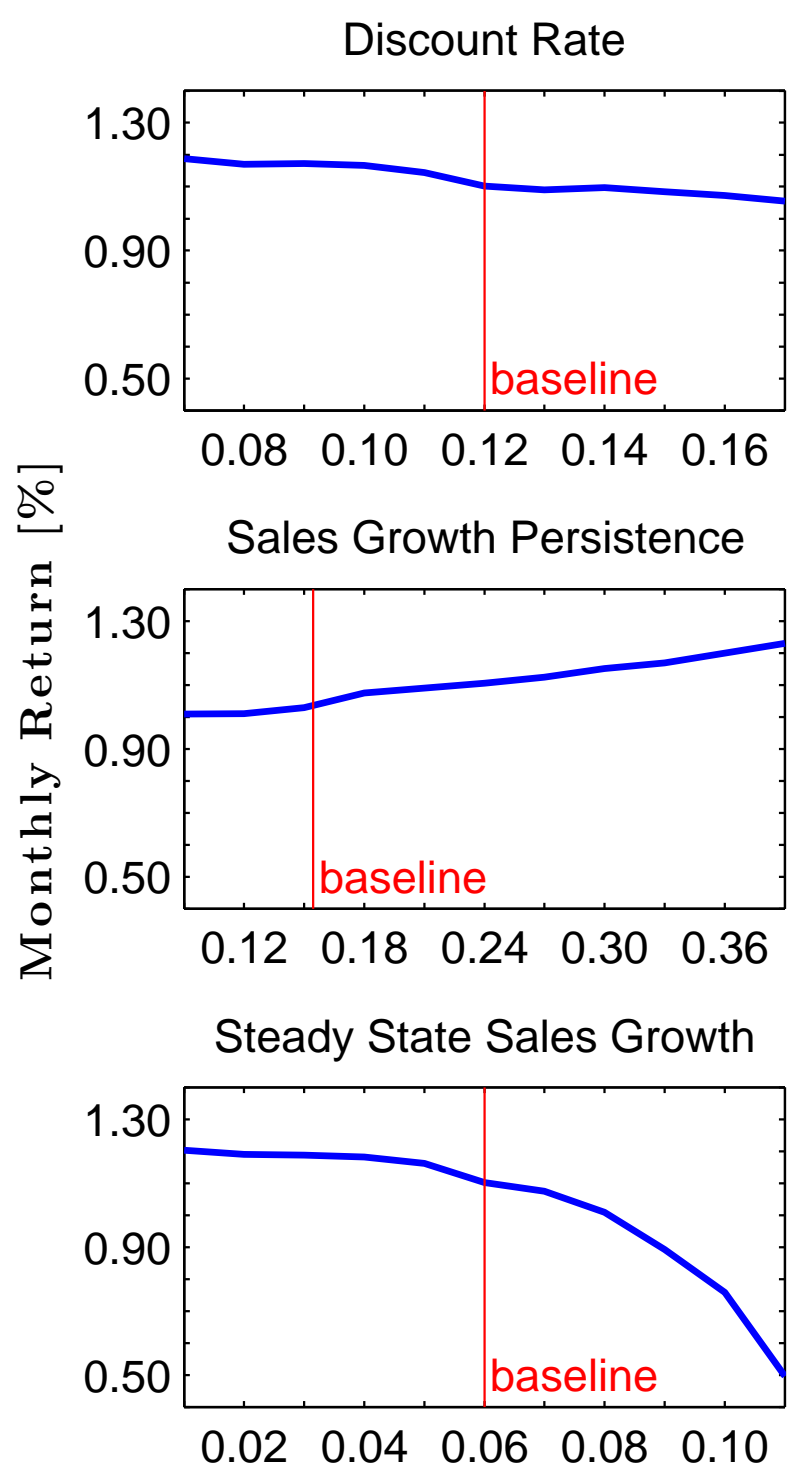

Forcast Horizon [years]

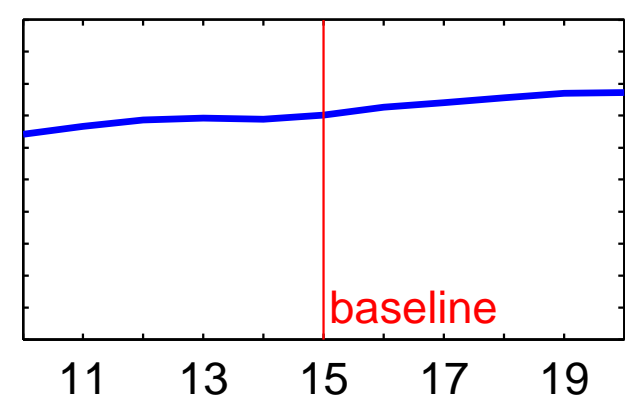

ROE Persistence

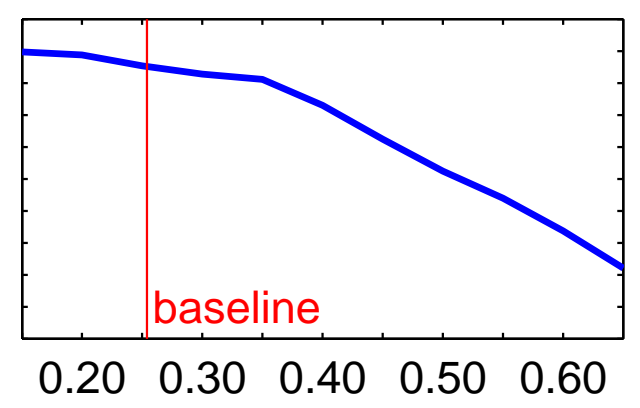

Steady State ROE

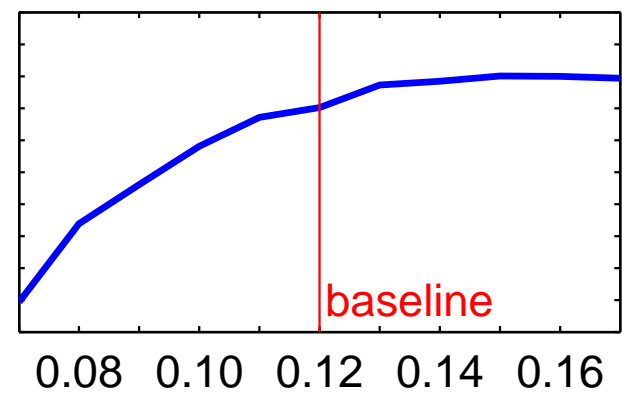

This figure plots monthly long-short excess returns for variations in the parameter values I use to construct cash flow duration at the firm level (see equation (2)). I sort all common stocks listed on NYSE, AMEX, and NASDAQ at the end of June each year t from 1963 to 2013 into deciles based on duration for all firms with fiscal years ending in year t-1. I weight returns equally and include delisting returns. If a firm is delisted for cause (delisting code between 400 and 591) and has missing delisting return, I assume a delisting return of -30\% following Shumway (1997). Financial statement data come from Compustat. For missing Compustat book equity values, I use the Moody's book equity information collected by Davis et al. (2000). 
Figure 3: Time Series of Returns

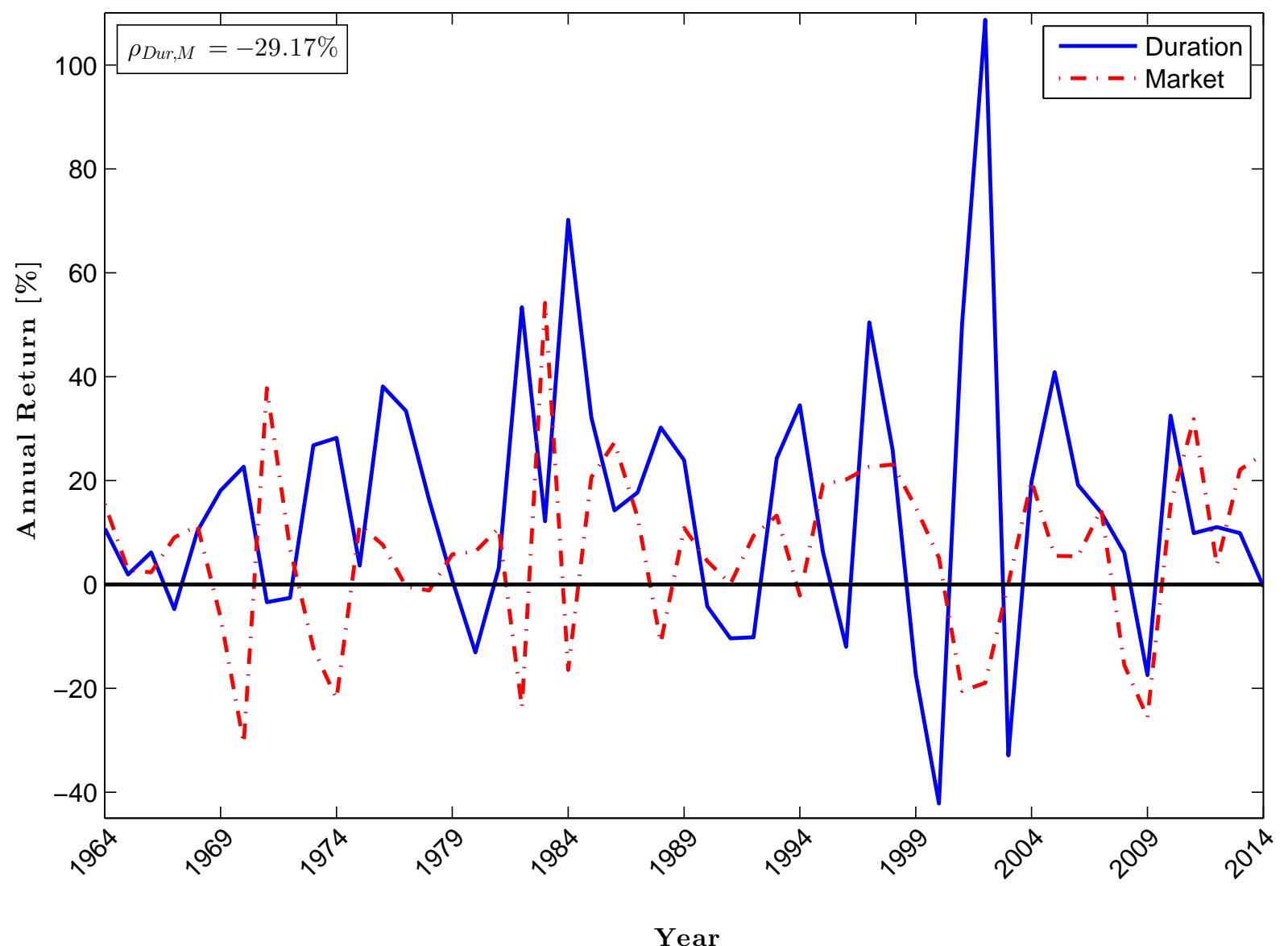

This figure plots annual long-short excess returns based on 10 cash flow duration sorted portfolios (blue line) and the market excess return (red dash-dotted line). I sort all common stocks listed on NYSE, $A M E X$, and NASDAQ at the end of June each year $t$ from 1963 to 2013 into deciles based on duration for all firms with fiscal years ending in year $t$-1. I weight returns equally and include delisting returns. If a firm is delisted for cause (delisting code between 400 and 591) and has missing delisting return, I assume a delisting return of -30\% following Shumway (1997). Financial statement data come from Compustat. For missing Compustat book equity values, I use the Moody's book equity information collected by Davis et al. (2000). 
Table 1: Summary Statistics and Correlations for Firm Characteristics and Return Predictors

This table reports time series averages of annual cross-sectional means and standard deviations for firm characteristics and return predictors in Panel $A$ and contemporaneous correlations of these variables in Panel B. Dur is cash-flow duration; BM is the book-to-market ratio; IOR is the fraction of shares institutions hold; $P R$ is net payout over net income; ROE is return on equity; Sales_g is sales growth; $M E$ is the market capitalization in millions; and Age is the number of years a firm has been on Compustat. Institutional ownership information is obtained from the Thomson Reuters $13 F$ database. Financial statement data come from Compustat. For missing Compustat book equity values, I use the Moody's book equity information collected by Davis et al. (2000). The sample period is June 1981 to June 2014. I only use stocks above the $20^{\text {th }}$ size percentile.

\begin{tabular}{|c|c|c|c|c|c|c|c|c|}
\hline & Dur & $\mathrm{BM}$ & IOR & $\mathrm{PR}$ & ROE & Sales_g & $\mathrm{ME}$ & Age \\
\hline & \multicolumn{8}{|c|}{ Panel A. Means and Standard Deviations } \\
\hline Mean & 18.77 & 0.67 & 0.44 & -0.01 & 0.05 & 0.22 & 2125 & 17.59 \\
\hline \multirow[t]{2}{*}{ Std } & 5.37 & 0.53 & 0.23 & 2.10 & 0.54 & 0.59 & 6197 & 11.46 \\
\hline & \multicolumn{8}{|c|}{ Panel B. Contemporaneous Correlations } \\
\hline Dur & & -0.70 & -0.08 & -0.10 & -0.39 & 0.34 & 0.04 & -0.19 \\
\hline $\mathrm{B} / \mathrm{M}$ & & & -0.01 & 0.08 & -0.04 & -0.16 & -0.11 & 0.11 \\
\hline IOR & & & & 0.06 & 0.18 & -0.10 & 0.22 & 0.26 \\
\hline $\mathrm{PR}$ & & & & & -0.05 & -0.24 & 0.08 & 0.20 \\
\hline $\mathrm{ROE}$ & & & & & & -0.02 & 0.10 & 0.09 \\
\hline Sale_g & & & & & & & -0.04 & -0.20 \\
\hline $\mathrm{ME}$ & & & & & & & & 0.30 \\
\hline
\end{tabular}




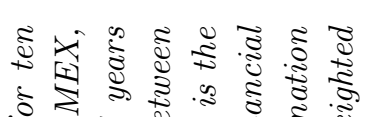

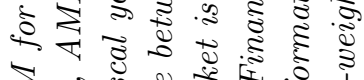

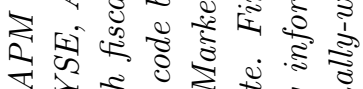

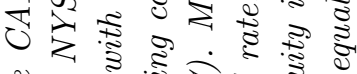

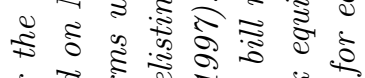

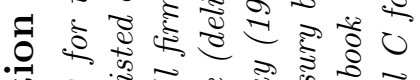

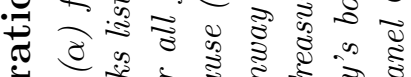

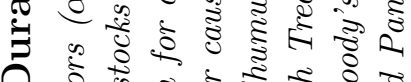
की के 万人

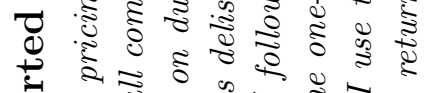

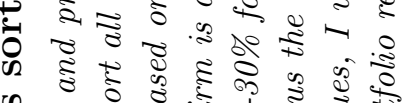

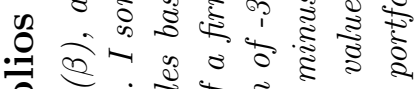

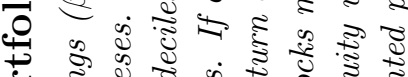

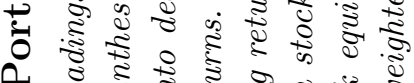
क

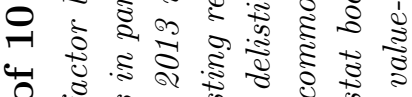

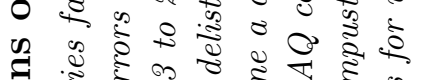

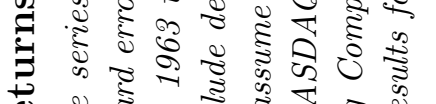

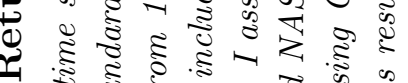
क की

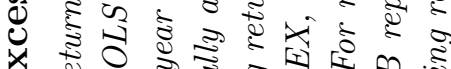

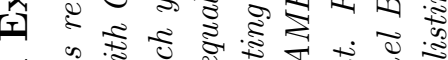
I वूँ

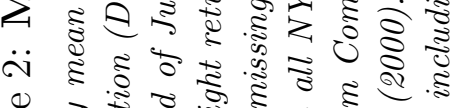

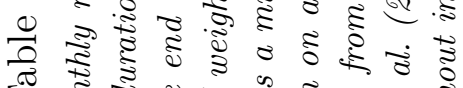

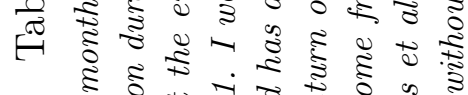

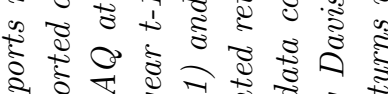

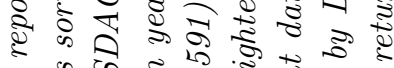
ব约

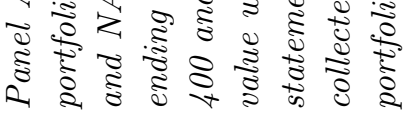

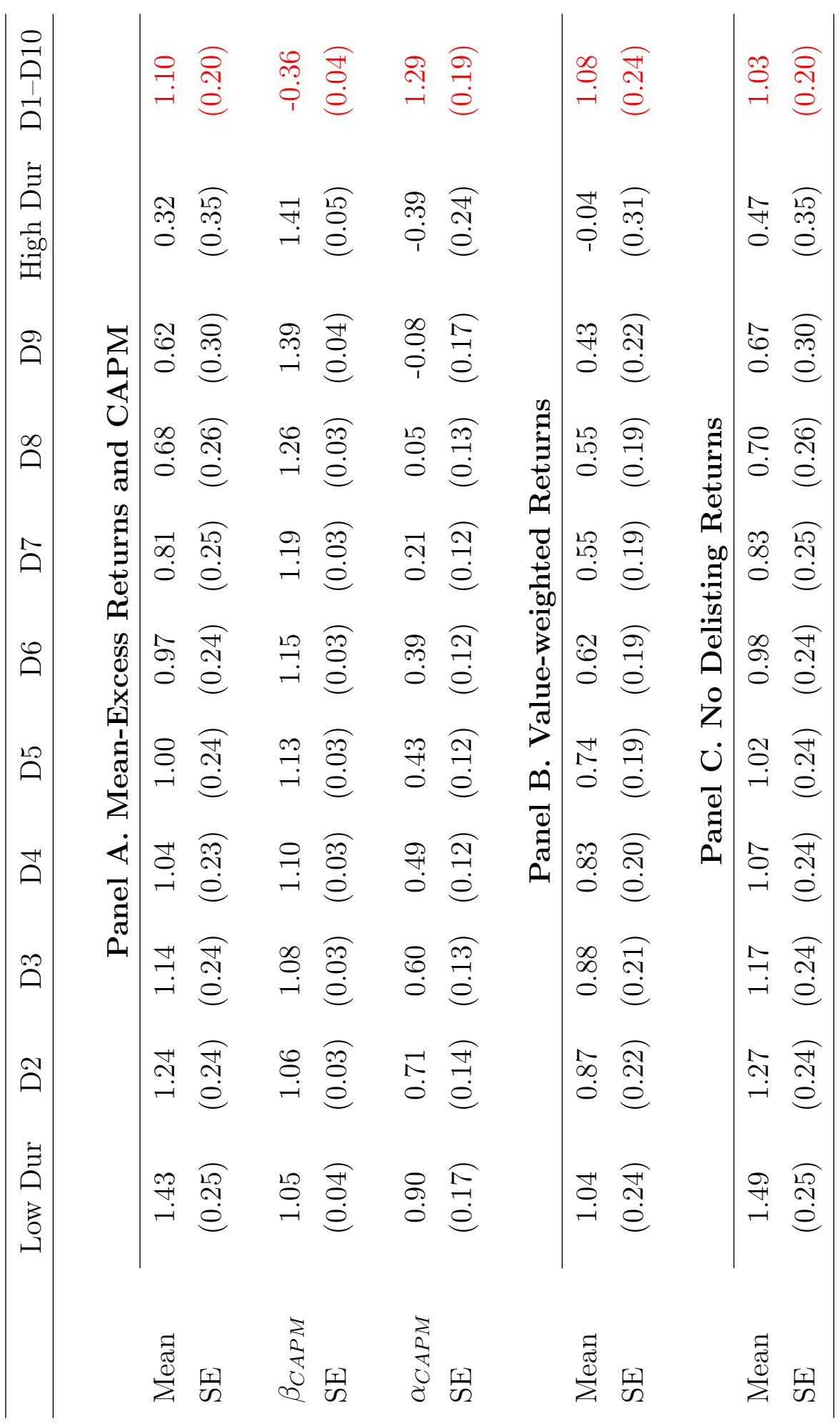




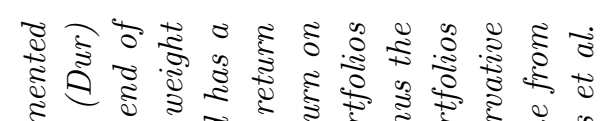

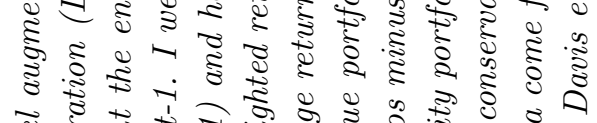

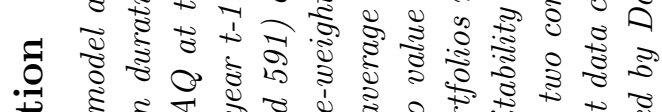
क

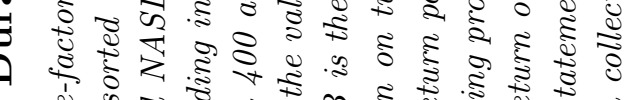

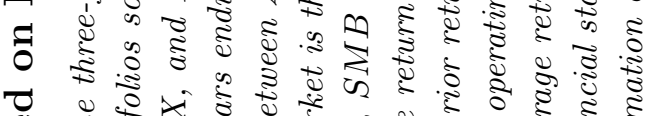

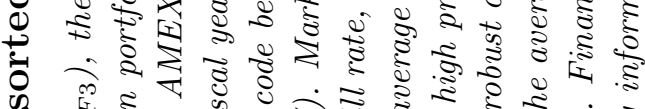

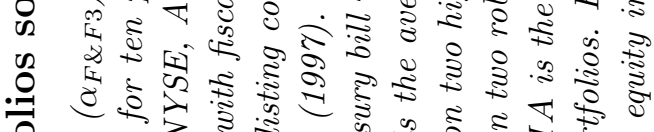

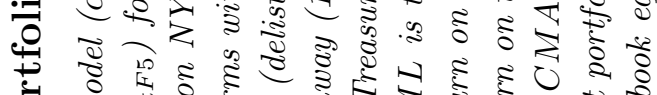

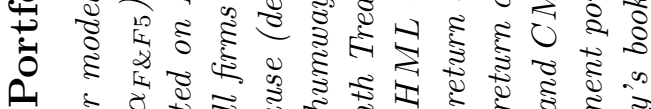

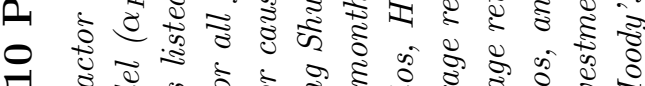

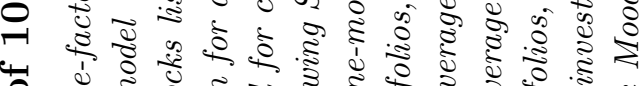
ธน

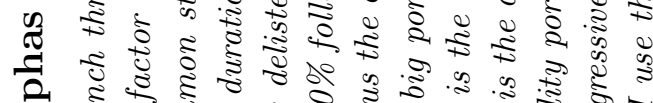
कํำ

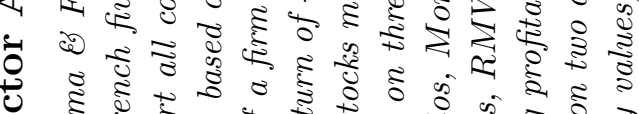

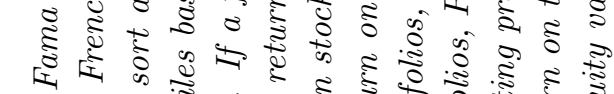

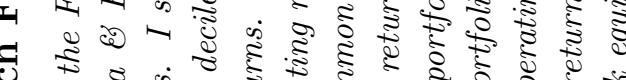

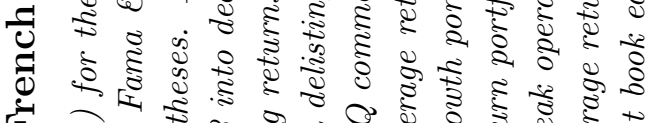

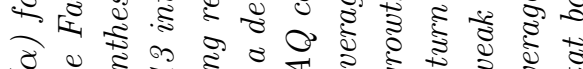

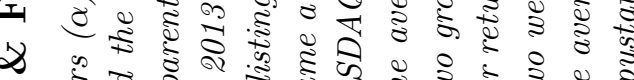

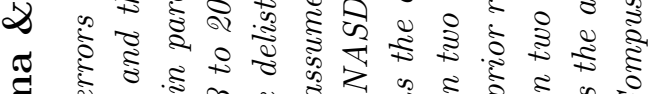
च है

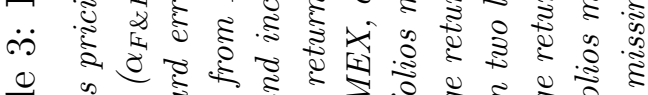
考若

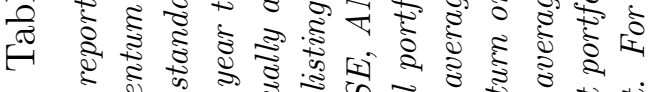

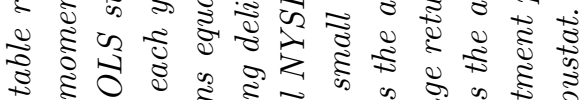

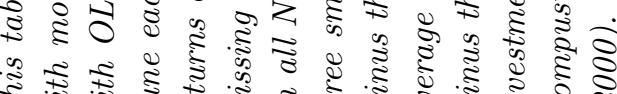

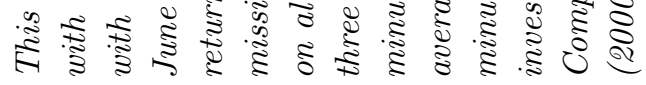

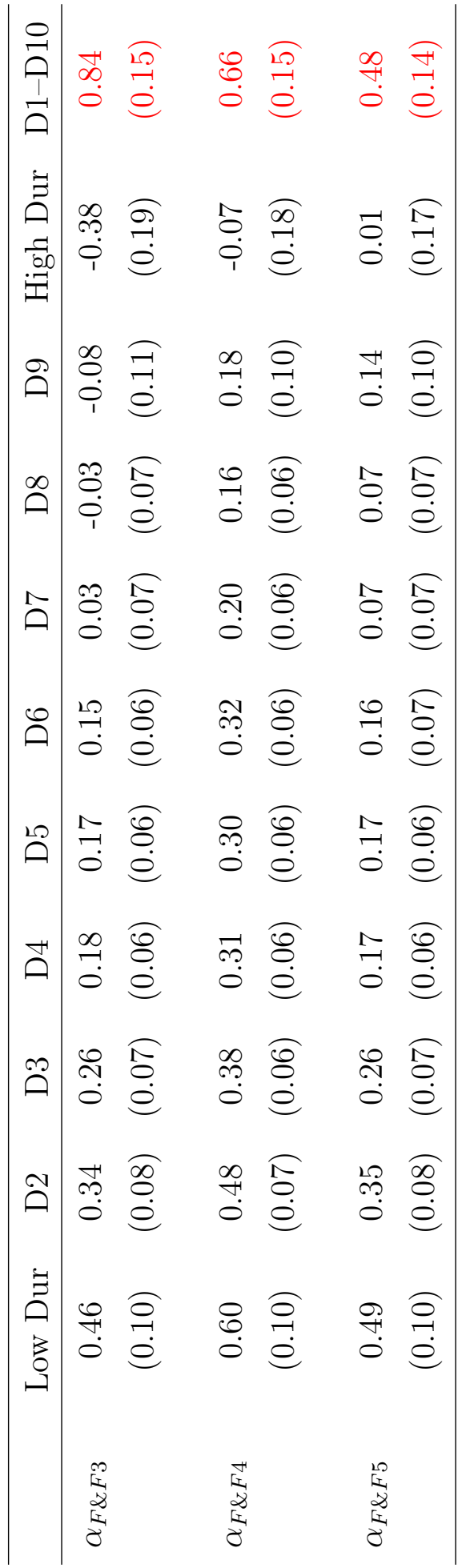




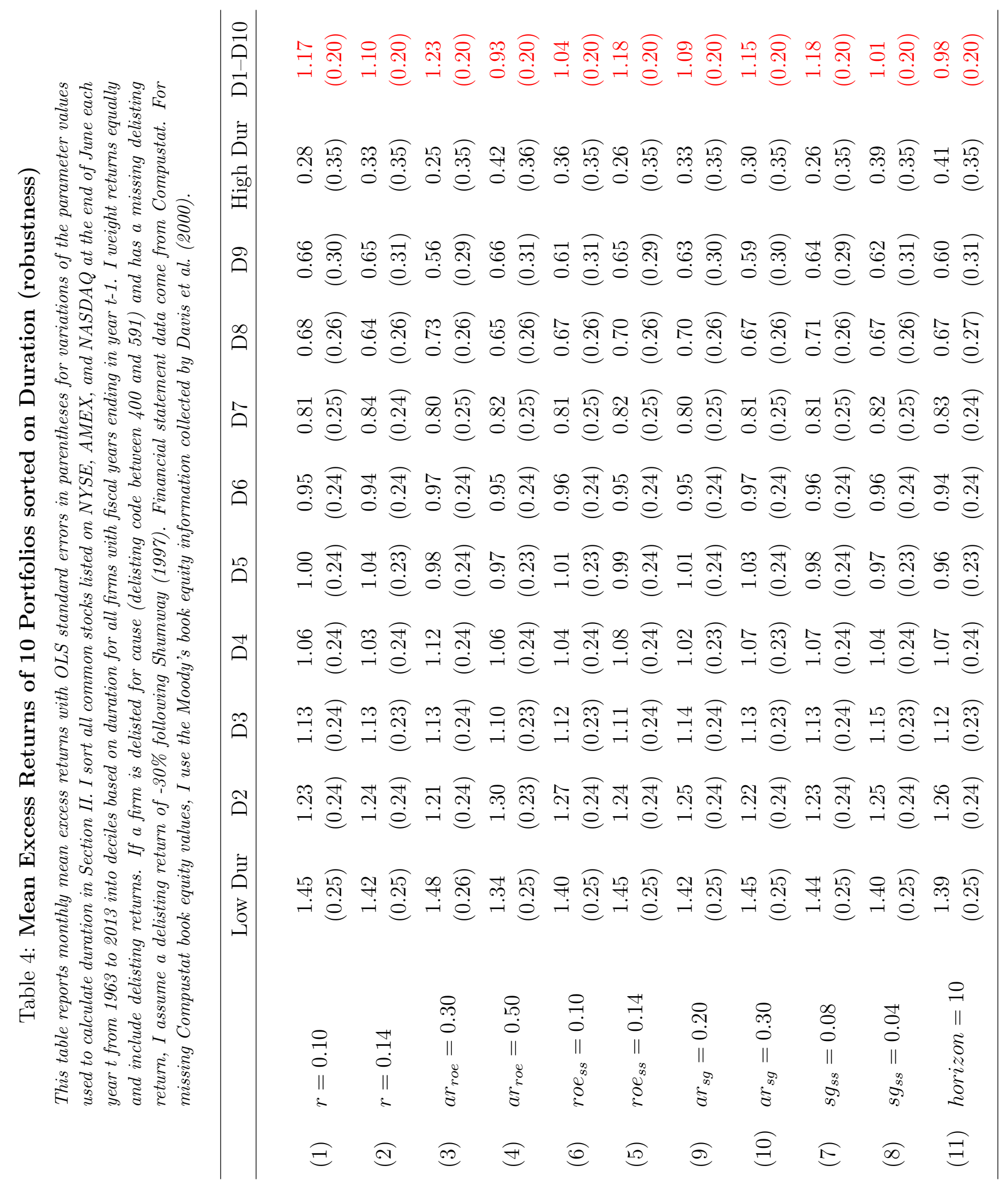




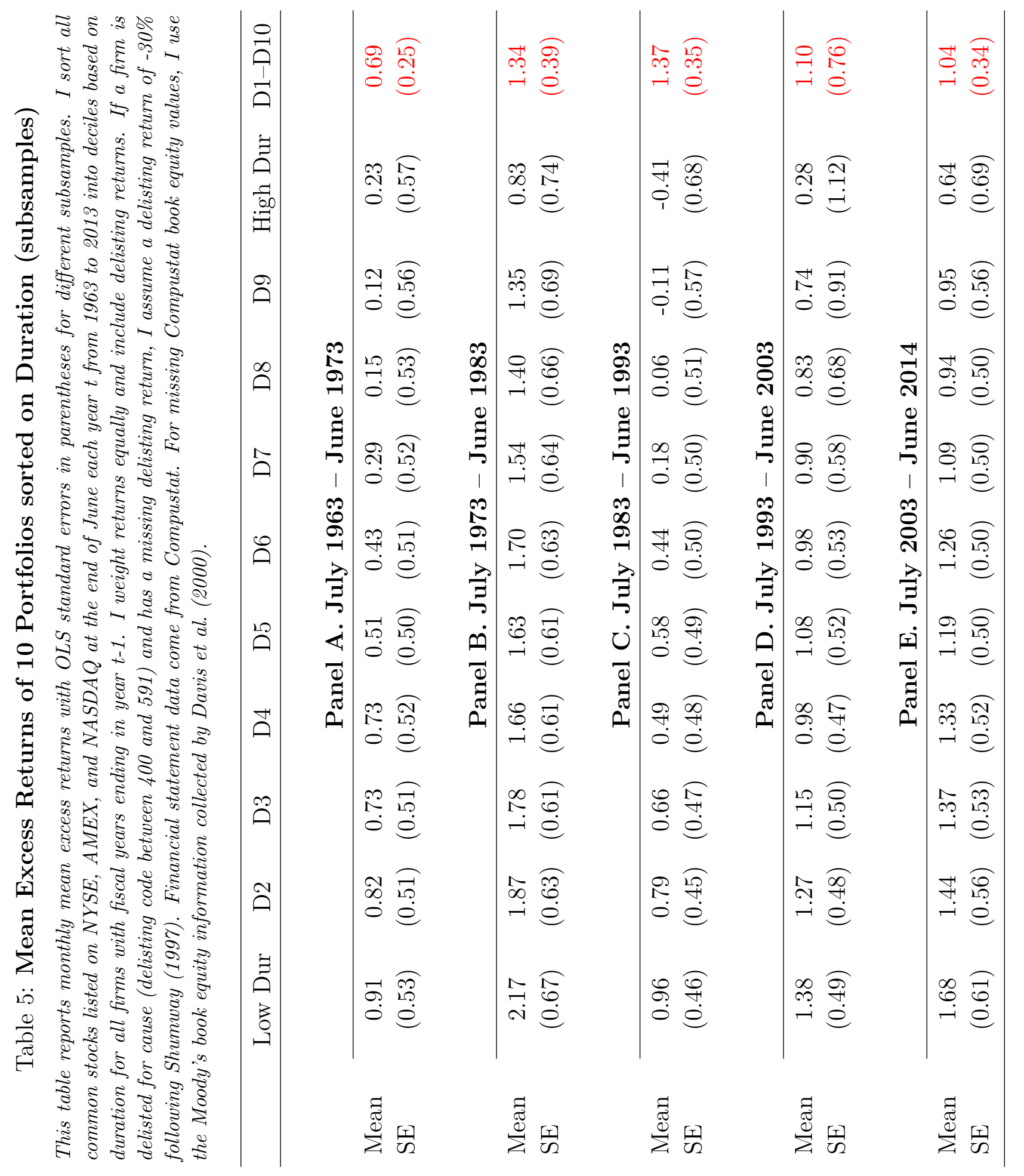




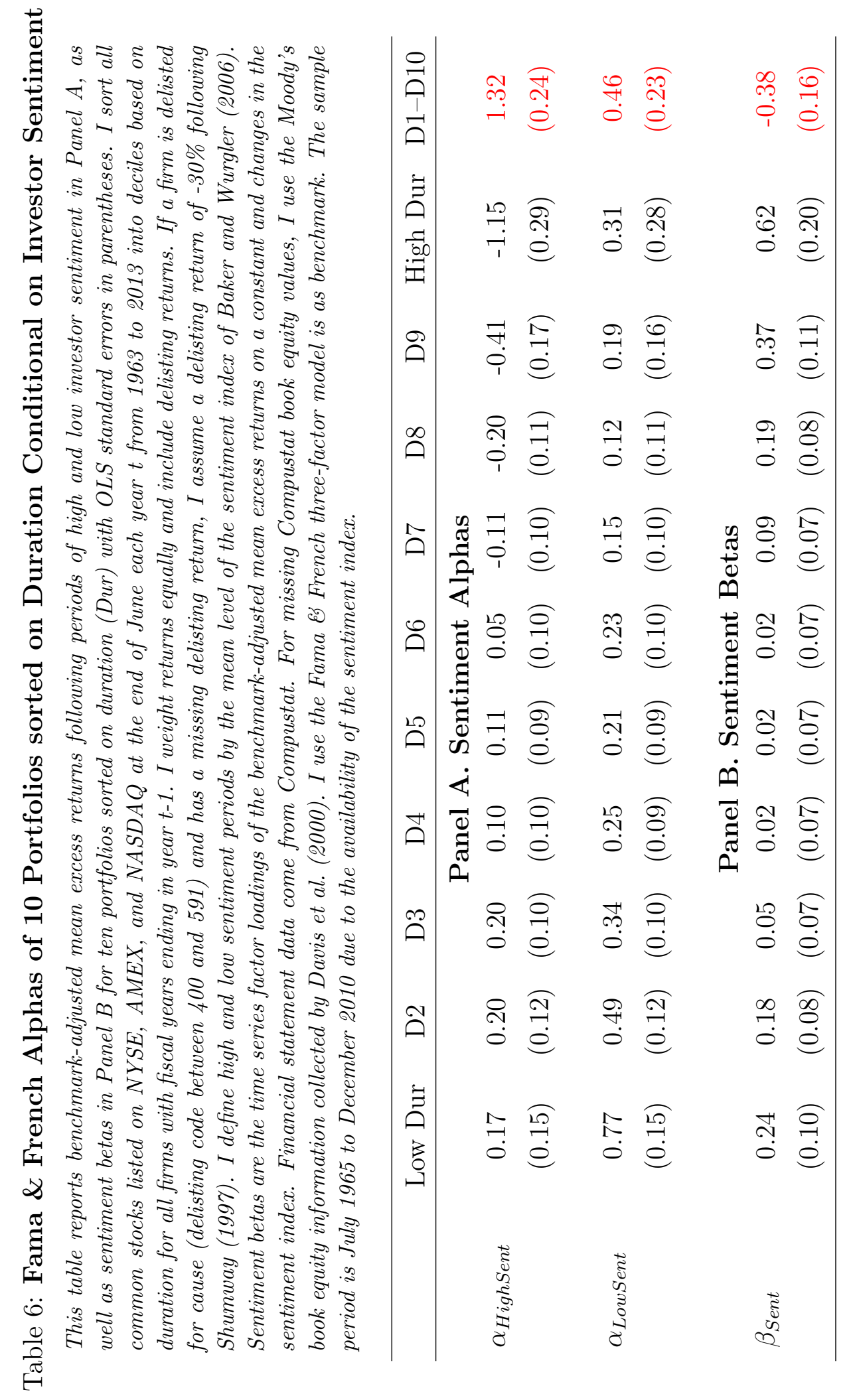




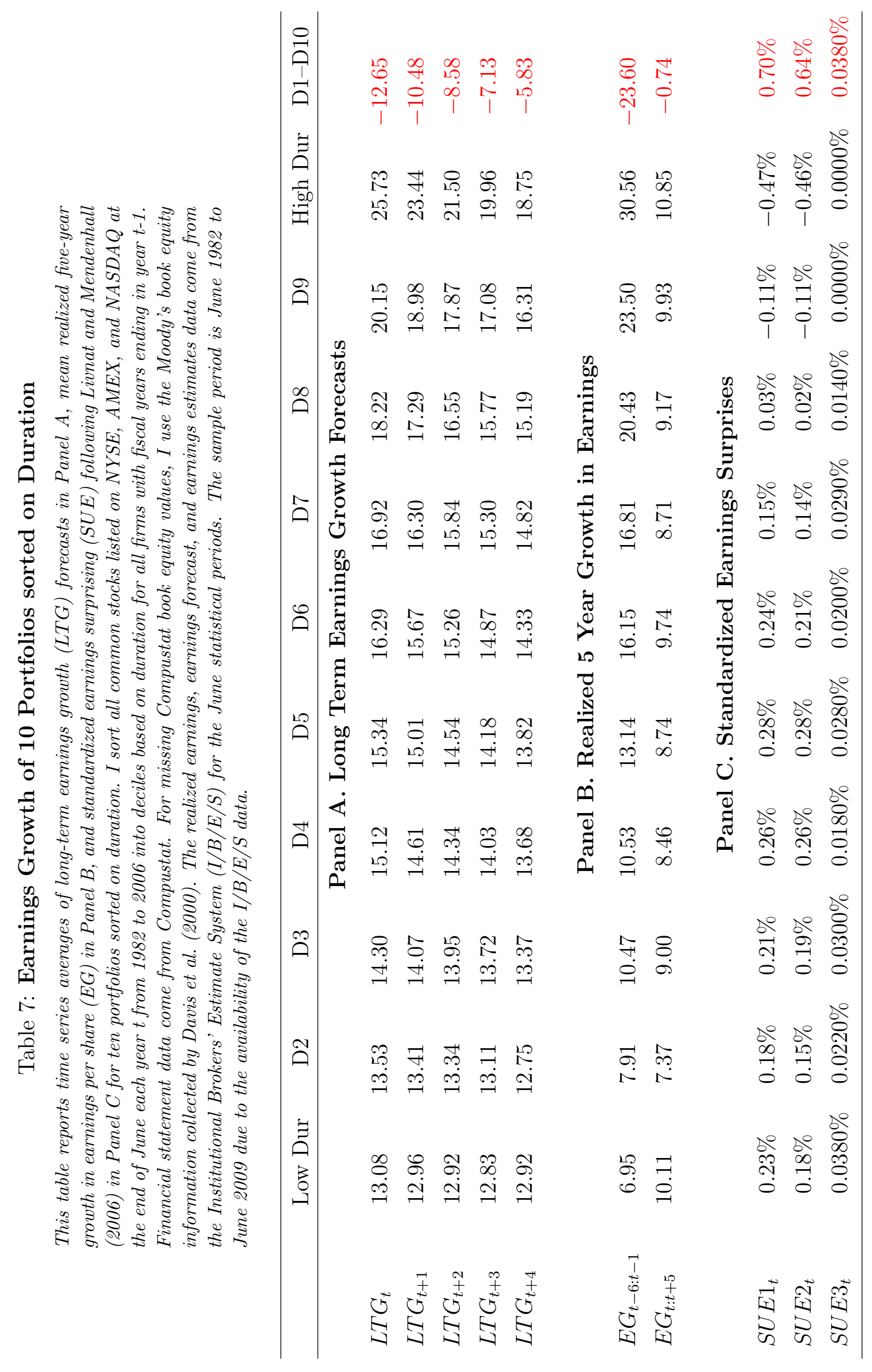


Table 8: Summary Statistics of 25 Portfolios sorted on Duration and Residual Institutional Ownership

This table reports time series averages of annual cross sectional means for firm characteristics and return predictors used in the subsequent analysis for twenty-five portfolios sorted on duration (Dur) and residual institutional ownership (RIOR). I sort all common stocks listed on NYSE, AMEX, and NASDAQ at the end of June each year $t$ from 1981 to 2013 into quintiles based on duration for all firms with fiscal years ending in year t-1. I intersected these quintiles with an independent sort on residual institutional ownership as of December t-1. Dur is cash flow duration; BM is the book-to-market ratio; IOR is the fraction of shares institutions hold; RIOR is the residual in a cross sectional regression of IOR on size; $P R$ is net payout over net income; ROE is return on equity; Sales_g is sales growth; ME is the market capitalization in millions; and Age is number of years a firm has been on Compustat. I obtain institutional ownership information from the Thomson Reuters $13 F$ database. Financial statement data come from Compustat. For missing Compustat book equity values, I use the Moody's book equity information collected by Davis et al. (2000). I only use stocks above the $20^{\text {th }}$ size percentile.

\begin{tabular}{|c|c|c|c|c|c|c|c|c|c|c|}
\hline & \multicolumn{5}{|c|}{ Duration } & \multicolumn{5}{|c|}{ Duration } \\
\hline & Low & D2 & D3 & D4 & High & Low & D2 & D3 & D4 & High \\
\hline & \multicolumn{5}{|c|}{ Panel A. Dur } & \multicolumn{5}{|c|}{ Panel B. BM } \\
\hline Low RIOR & 10.87 & 17.23 & 19.41 & 21.20 & 25.04 & 1.21 & 0.74 & 0.53 & 0.35 & 0.24 \\
\hline RIOR 2 & 11.70 & 17.19 & 19.38 & 21.18 & 24.61 & 1.21 & 0.75 & 0.53 & 0.35 & 0.27 \\
\hline RIOR 3 & 11.79 & 17.19 & 19.37 & 21.15 & 24.67 & 1.25 & 0.77 & 0.54 & 0.36 & 0.30 \\
\hline RIOR 4 & 11.48 & 17.14 & 19.38 & 21.13 & 24.47 & 1.34 & 0.80 & 0.57 & 0.41 & 0.33 \\
\hline \multirow[t]{2}{*}{ High RIOR } & 11.18 & 17.10 & 19.36 & 21.13 & 24.53 & 1.47 & 0.87 & 0.63 & 0.45 & 0.40 \\
\hline & \multicolumn{5}{|c|}{ Panel C. IOR } & \multicolumn{5}{|c|}{ Panel D. PR } \\
\hline Low RIOR & 0.21 & 0.24 & 0.26 & 0.25 & 0.15 & 0.08 & 0.10 & 0.14 & -0.14 & -1.04 \\
\hline RIOR 2 & 0.37 & 0.41 & 0.44 & 0.45 & 0.34 & 0.29 & 0.30 & 0.19 & 0.00 & -0.51 \\
\hline RIOR 3 & 0.42 & 0.48 & 0.52 & 0.53 & 0.42 & 0.25 & 0.21 & 0.08 & -0.09 & -0.75 \\
\hline RIOR 4 & 0.45 & 0.52 & 0.55 & 0.57 & 0.48 & 0.32 & 0.15 & -0.02 & -0.25 & -0.74 \\
\hline \multirow[t]{2}{*}{ High RIOR } & 0.55 & 0.60 & 0.63 & 0.64 & 0.59 & 0.27 & 0.06 & -0.25 & -0.48 & -1.12 \\
\hline & \multicolumn{5}{|c|}{ Panel E. ROE } & \multicolumn{5}{|c|}{ Panel F. Sales_g } \\
\hline Low RIOR & 0.42 & 0.16 & 0.16 & 0.17 & -0.49 & 0.12 & 0.11 & 0.14 & 0.20 & 0.73 \\
\hline RIOR 2 & 0.27 & 0.14 & 0.15 & 0.18 & -0.31 & 0.06 & 0.09 & 0.13 & 0.20 & 0.59 \\
\hline RIOR 3 & 0.20 & 0.12 & 0.14 & 0.16 & -0.31 & 0.05 & 0.09 & 0.14 & 0.20 & 0.58 \\
\hline RIOR 4 & 0.16 & 0.10 & 0.12 & 0.13 & -0.31 & 0.04 & 0.09 & 0.14 & 0.21 & 0.56 \\
\hline \multirow[t]{2}{*}{ High RIOR } & 0.12 & 0.09 & 0.11 & 0.12 & -0.35 & 0.03 & 0.09 & 0.14 & 0.22 & 0.51 \\
\hline & \multicolumn{5}{|c|}{ Panel G. AGE } & \multicolumn{5}{|c|}{ Panel H. ME } \\
\hline Low RIOR & 17.10 & 19.14 & 18.99 & 17.12 & 10.99 & 1639 & 1905 & 2588 & 2834 & 1224 \\
\hline RIOR 2 & 21.34 & 22.69 & 22.34 & 19.92 & 12.72 & 2304 & 2854 & 3791 & 4953 & 2451 \\
\hline RIOR 3 & 20.99 & 22.26 & 20.73 & 18.74 & 12.51 & 1565 & 2229 & 3022 & 4568 & 2529 \\
\hline RIOR 4 & 20.20 & 20.34 & 18.30 & 15.75 & 11.73 & 673 & 1305 & 1915 & 3251 & 1633 \\
\hline High RIOR & 17.96 & 17.05 & 14.99 & 12.75 & 11.16 & 305 & 566 & 1151 & 1311 & 955 \\
\hline
\end{tabular}


Table 9: Mean Excess Returns of 25 Portfolios sorted on Duration and Residual Institutional Ownership

This table reports monthly mean excess returns for twenty-five portfolios sorted on duration (Dur) and residual institutional ownership (RIOR) with OLS standard errors in parentheses. I sort all common stocks listed on NYSE, AMEX, and NASDAQ at the end of June each year $t$ from 1981 to 2013 into quintiles based on duration for all firms with fiscal years ending in year $t$-1. I intersect these quintiles with an independent sort on residual institutional ownership as of December $t$ - 1 . I weight returns equally and include delisting returns. If a firm is delisted for cause (delisting code between 400 and 591) and has a missing delisting return, I assume a delisting return of $-30 \%$ following Shumway (1997). Dur is cash flow duration. RIOR is the residual in a cross sectional regression of the fraction of shares held by institutions on size. Institutional ownership information is obtained from the Thomson Reuters $13 F$ database. Financial statement data come from Compustat. For missing Compustat book equity values, I use the Moody's book equity information collected by Davis et al. (2000). I only use stocks above the $20^{\text {th }}$ size percentile.

\begin{tabular}{lcccccc}
\hline & Low Dur & D2 & D3 & D4 & High Dur & D1-D5 \\
\hline Low RIOR & 1.02 & 0.84 & 0.75 & 0.47 & -0.30 & 1.32 \\
& $(0.29)$ & $(0.29)$ & $(0.29)$ & $(0.33)$ & $(0.45)$ & $(0.27)$ \\
RIOR2 & 1.08 & 0.96 & 0.85 & 0.73 & 0.25 & 0.83 \\
& $(0.29)$ & $(0.28)$ & $(0.28)$ & $(0.29)$ & $(0.42)$ & $(0.24)$ \\
\multirow{2}{*}{ RIOR3 } & 1.09 & 0.97 & 0.95 & 0.78 & 0.47 & 0.62 \\
$\underset{\Xi}{\Xi}$ RIOR4 & $(0.29)$ & $(0.28)$ & $(0.28)$ & $(0.31)$ & $(0.42)$ & $(0.26)$ \\
& 1.04 & 1.02 & 0.91 & 0.64 & 0.52 & 0.52 \\
High RIOR & $(0.28)$ & $(0.29)$ & $(0.30)$ & $(0.33)$ & $(0.43)$ & $(0.27)$ \\
& 1.09 & 1.01 & 0.93 & 0.76 & 0.94 & 0.15 \\
RIOR1 - RIOR5 & $(0.31)$ & $(0.31)$ & $(0.31)$ & $(0.33)$ & $(0.42)$ & $(0.26)$ \\
& -0.08 & -0.17 & -0.18 & -0.29 & -1.24 & 1.17 \\
& $(0.13)$ & $(0.13)$ & $(0.12)$ & $(0.13)$ & $(0.22)$ & $(0.23)$ \\
\hline
\end{tabular}


Table 10: CAPM Alphas 25 Portfolios sorted on Duration and Residual Institutional Ownership

This table reports pricing errors ( $\alpha$ ) for the CAPM for twenty-five portfolios sorted on duration (Dur) and residual institutional ownership (RIOR) with OLS standard errors in parentheses. I sort all common stocks listed on NYSE, AMEX, and NASDAQ at the end of June each year $t$ from 1981 to 2013 into quintiles based on duration for all firms with fiscal years ending in year t-1. I intersect these quintiles with an independent sort on residual institutional ownership as of December $t$ - 1 . I weight returns equally and include delisting returns. If a firm is delisted for cause (delisting code between 400 and 591) and has a missing delisting return, I assume a delisting return of -30\% following Shumway (1997). Market is the value weighted return on all NYSE, AMEX, and NASDAQ common stocks minus the one-month Treasury bill rate, $S M B$ is the average return on three small portfolios minus the average return on three big portfolios, and HML is the average return on two value portfolios minus the average return on two growth portfolios. Dur is cash flow duration. RIOR is the residual in a cross sectional regression of the fraction of shares held by institutions on size. Institutional ownership information is obtained from the Thomson Reuters $13 F$ database. Financial statement data come from Compustat. For missing Compustat book equity values, I use the Moody's book equity information collected by Davis et al. (2000). I only use stocks above the $20^{\text {th }}$ size percentile.

\begin{tabular}{|c|c|c|c|c|c|c|c|}
\hline & & Low Dur & D2 & D3 & $\mathrm{D} 4$ & High Dur & D1-D5 \\
\hline \multirow{6}{*}{$\begin{array}{l}z \\
Z \\
Z \\
Z\end{array}$} & Low RIOR & $\begin{array}{c}0.37 \\
(0.19)\end{array}$ & $\begin{array}{c}0.17 \\
(0.16)\end{array}$ & $\begin{array}{c}0.06 \\
(0.15)\end{array}$ & $\begin{array}{l}-0.29 \\
(0.18)\end{array}$ & $\begin{array}{l}-1.23 \\
(0.32)\end{array}$ & $\begin{array}{c}1.61 \\
(0.26)\end{array}$ \\
\hline & RIOR2 & $\begin{array}{c}0.40 \\
(0.17)\end{array}$ & $\begin{array}{c}0.26 \\
(0.14)\end{array}$ & $\begin{array}{c}0.14 \\
(0.12)\end{array}$ & $\begin{array}{l}-0.01 \\
(0.12)\end{array}$ & $\begin{array}{c}-0.69 \\
(0.26)\end{array}$ & $\begin{array}{c}1.09 \\
(0.23)\end{array}$ \\
\hline & RIOR3 & $\begin{array}{c}0.41 \\
(0.17)\end{array}$ & $\begin{array}{c}0.28 \\
(0.14)\end{array}$ & $\begin{array}{c}0.24 \\
(0.13)\end{array}$ & $\begin{array}{c}0.00 \\
(0.14)\end{array}$ & $\begin{array}{l}-0.47 \\
(0.26)\end{array}$ & $\begin{array}{c}0.88 \\
(0.25)\end{array}$ \\
\hline & RIOR4 & $\begin{array}{c}0.40 \\
(0.17)\end{array}$ & $\begin{array}{c}0.33 \\
(0.16)\end{array}$ & $\begin{array}{c}0.18 \\
(0.15)\end{array}$ & $\begin{array}{l}-0.17 \\
(0.16)\end{array}$ & $\begin{array}{l}-0.40 \\
(0.28)\end{array}$ & $\begin{array}{c}0.79 \\
(0.26)\end{array}$ \\
\hline & High RIOR & $\begin{array}{c}0.42 \\
(0.20)\end{array}$ & $\begin{array}{c}0.30 \\
(0.18)\end{array}$ & $\begin{array}{c}0.21 \\
(0.18)\end{array}$ & $\begin{array}{l}-0.02 \\
(0.18)\end{array}$ & $\begin{array}{c}0.03 \\
(0.27)\end{array}$ & $\begin{array}{c}0.40 \\
(0.24)\end{array}$ \\
\hline & RIOR1 - RIOR5 & $\begin{array}{l}-0.05 \\
(0.14)\end{array}$ & $\begin{array}{l}-0.13 \\
(0.13)\end{array}$ & $\begin{array}{l}-0.15 \\
(0.12)\end{array}$ & $\begin{array}{l}-0.28 \\
(0.13)\end{array}$ & $\begin{array}{l}-1.26 \\
(0.22)\end{array}$ & $\begin{array}{c}1.21 \\
(0.23)\end{array}$ \\
\hline
\end{tabular}


Table 11: Fama - French Alphas of 25 Portfolios sorted on Duration and Residual Institutional Ownership

This table reports pricing errors ( $\alpha$ ) for the Fama \& French three-factor model for twenty-five portfolios sorted on duration (Dur) and residual institutional ownership (RIOR) with OLS standard errors in parentheses. I sort all common stocks listed on NYSE, AMEX, and NASDAQ at the end of June each year $t$ from 1981 to 2013 into quintiles based on duration for all firms with fiscal years ending in year $t$ - 1 . I intersect these quintiles with an independent sort on residual institutional ownership as of December $t$-1. I weight returns equally and include delisting returns. If a firm is delisted for cause (delisting code between 400 and 591) and has a missing delisting return, I assume a delisting return of -30\% following Shumway (1997). Market is the value weighted return on all NYSE, AMEX, and NASDAQ common stocks minus the one-month Treasury bill rate, $S M B$ is the average return on three small portfolios minus the average return on three big portfolios, $H M L$ is the average return on two value portfolios minus the average return on two growth portfolios, and Mom is the average return on two high prior return portfolios minus the average return on two low prior return portfolios. Dur is cash flow duration. RIOR is the residual in a crosssectional regression of the fraction of shares held by institutions on size. Institutional ownership information is obtained from the Thomson Reuters $13 F$ database. Financial statement data come from Compustat. For missing Compustat book equity values, I use the Moody's book equity information collected by Davis et al. (2000). I only use stocks above the $20^{\text {th }}$ size percentile.

\begin{tabular}{|c|c|c|c|c|c|c|c|}
\hline & & Low Dur & D2 & D3 & $\mathrm{D} 4$ & High Dur & D1-D5 \\
\hline \multirow{6}{*}{$\begin{array}{l}5 \\
5 \\
2 \\
5 \\
8\end{array}$} & Low RIOR & $\begin{array}{c}0.16 \\
(0.13)\end{array}$ & $\begin{array}{c}0.06 \\
(0.13)\end{array}$ & $\begin{array}{c}0.00 \\
(0.11)\end{array}$ & $\begin{array}{l}-0.22 \\
(0.14)\end{array}$ & $\begin{array}{l}-1.01 \\
(0.24)\end{array}$ & $\begin{array}{c}1.17 \\
(0.21)\end{array}$ \\
\hline & RIOR2 & $\begin{array}{c}0.17 \\
(0.12)\end{array}$ & $\begin{array}{c}0.12 \\
(0.09)\end{array}$ & $\begin{array}{c}0.05 \\
(0.08)\end{array}$ & $\begin{array}{c}0.03 \\
(0.09)\end{array}$ & $\begin{array}{l}-0.47 \\
(0.18)\end{array}$ & $\begin{array}{c}0.64 \\
(0.18)\end{array}$ \\
\hline & RIOR3 & $\begin{array}{c}0.12 \\
(0.11)\end{array}$ & $\begin{array}{c}0.05 \\
(0.09)\end{array}$ & $\begin{array}{c}0.14 \\
(0.09)\end{array}$ & $\begin{array}{c}0.05 \\
(0.09)\end{array}$ & $\begin{array}{c}-0.24 \\
(0.18)\end{array}$ & $\begin{array}{c}0.36 \\
(0.18)\end{array}$ \\
\hline & RIOR4 & $\begin{array}{c}0.13 \\
(0.11)\end{array}$ & $\begin{array}{c}0.12 \\
(0.09)\end{array}$ & $\begin{array}{c}0.05 \\
(0.10)\end{array}$ & $\begin{array}{c}-0.14 \\
(0.11)\end{array}$ & $\begin{array}{l}-0.16 \\
(0.20)\end{array}$ & $\begin{array}{c}0.29 \\
(0.20)\end{array}$ \\
\hline & High RIOR & $\begin{array}{c}0.08 \\
(0.13)\end{array}$ & $\begin{array}{c}0.10 \\
(0.11)\end{array}$ & $\begin{array}{c}0.06 \\
(0.11)\end{array}$ & $\begin{array}{c}0.01 \\
(0.13)\end{array}$ & $\begin{array}{c}0.13 \\
(0.20)\end{array}$ & $\begin{array}{l}-0.05 \\
(0.20)\end{array}$ \\
\hline & RIOR1-RIOR5 & $\begin{array}{c}0.08 \\
(0.13)\end{array}$ & $\begin{array}{l}-0.04 \\
(0.13)\end{array}$ & $\begin{array}{l}-0.05 \\
(0.12)\end{array}$ & $\begin{array}{l}-0.23 \\
(0.13)\end{array}$ & $\begin{array}{l}-1.14 \\
(0.22)\end{array}$ & $\begin{array}{c}1.22 \\
(0.23)\end{array}$ \\
\hline
\end{tabular}


Table 12: Four Factor Alphas of 25 Portfolios sorted on Duration and Residual Institutional Ownership

This table reports pricing errors ( $\alpha$ ) for Fama $\&$ French three-factor model augmented with momentum for twenty-five portfolios sorted on duration (Dur) and residual institutional ownership (RIOR) with OLS standard errors in parentheses. I sort all common stocks listed on NYSE, AMEX, and NASDAQ at the end of June each year $t$ from 1981 to 2013 into quintiles based on duration for all firms with fiscal years ending in year $t$-1. I intersect these quintiles with an independent sort on residual institutional ownership as of December $t$-1. I weight returns equally and include delisting returns. If a firm is delisted for cause (delisting code between 400 and 591) and has a missing delisting return, I assume a delisting return of -30\% following Shumway (1997). Market is the value-weighted return on all NYSE, AMEX, and $N A S D A Q$ common stocks minus the one-month Treasury bill rate, SMB is the average return on three small portfolios minus the average return on three big portfolios, $H M L$ is the average return on two value portfolios minus the average return on two growth portfolios, RMW is the average return on two robust operating profitability portfolios minus the average return on two weak operating profitability portfolios, and CMA is the average return on two conservative investment portfolios minus the average return on two aggressive investment portfolios. Dur is cash flow duration. RIOR is the residual in a cross sectional regression of the fraction of shares held by institutions on size. Institutional ownership information is obtained from the Thomson Reuters $13 F$ database. Financial statement data come from Compustat. For missing Compustat book equity values, I use the Moody's book equity information collected by Davis et al. (2000). I only use stocks above the $20^{\text {th }}$ size percentile.

\begin{tabular}{|c|c|c|c|c|c|c|c|}
\hline & & Low Dur & D2 & D3 & D4 & High Dur & D1-D5 \\
\hline \multirow{6}{*}{ 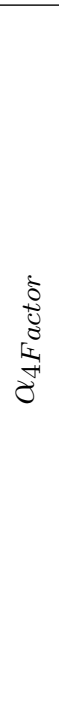 } & Low RIOR & $\begin{array}{c}0.38 \\
(0.12)\end{array}$ & $\begin{array}{c}0.28 \\
(0.11)\end{array}$ & $\begin{array}{c}0.19 \\
(0.10)\end{array}$ & $\begin{array}{c}0.05 \\
(0.12)\end{array}$ & $\begin{array}{l}-0.56 \\
(0.22)\end{array}$ & $\begin{array}{c}0.94 \\
(0.20)\end{array}$ \\
\hline & RIOR2 & $\begin{array}{c}0.35 \\
(0.11)\end{array}$ & $\begin{array}{c}0.25 \\
(0.08)\end{array}$ & $\begin{array}{c}0.22 \\
(0.07)\end{array}$ & $\begin{array}{c}0.20 \\
(0.08)\end{array}$ & $\begin{array}{l}-0.10 \\
(0.16)\end{array}$ & $\begin{array}{c}0.45 \\
(0.18)\end{array}$ \\
\hline & RIOR3 & $\begin{array}{c}0.29 \\
(0.10)\end{array}$ & $\begin{array}{c}0.18 \\
(0.09)\end{array}$ & $\begin{array}{c}0.26 \\
(0.08)\end{array}$ & $\begin{array}{c}0.24 \\
(0.08)\end{array}$ & $\begin{array}{c}0.09 \\
(0.16)\end{array}$ & $\begin{array}{c}0.20 \\
(0.18)\end{array}$ \\
\hline & RIOR4 & $\begin{array}{c}0.28 \\
(0.10)\end{array}$ & $\begin{array}{c}0.25 \\
(0.09)\end{array}$ & $\begin{array}{c}0.22 \\
(0.09)\end{array}$ & $\begin{array}{c}0.08 \\
(0.09)\end{array}$ & $\begin{array}{c}0.17 \\
(0.18)\end{array}$ & $\begin{array}{c}0.11 \\
(0.20)\end{array}$ \\
\hline & High RIOR & $\begin{array}{c}0.29 \\
(0.12)\end{array}$ & $\begin{array}{c}0.28 \\
(0.10)\end{array}$ & $\begin{array}{c}0.25 \\
(0.10)\end{array}$ & $\begin{array}{c}0.19 \\
(0.12)\end{array}$ & $\begin{array}{c}0.39 \\
(0.19)\end{array}$ & $\begin{array}{l}-0.10 \\
(0.21)\end{array}$ \\
\hline & RIOR1-RIOR5 & $\begin{array}{c}0.09 \\
(0.13)\end{array}$ & $\begin{array}{c}0.00 \\
(0.13)\end{array}$ & $\begin{array}{l}-0.06 \\
(0.12)\end{array}$ & $\begin{array}{l}-0.14 \\
(0.14)\end{array}$ & $\begin{array}{l}-0.95 \\
(0.22)\end{array}$ & $\begin{array}{c}1.04 \\
(0.23)\end{array}$ \\
\hline
\end{tabular}


Table 13: Five Factor Alphas of 25 Portfolios sorted on Duration and Residual Institutional Ownership

This table reports pricing errors ( $\alpha$ ) for the Fama $\&$ French five-factor model for twenty-five portfolios sorted on duration (Dur) and residual institutional ownership (RIOR) with OLS standard errors in parentheses. I sort all common stocks listed on NYSE, AMEX, and NASDAQ at the end of June each year $t$ from 1981 to 2013 into quintiles based on duration for all firms with fiscal years ending in year $t$-1. I intersect these quintiles with an independent sort on residual institutional ownership as of December $t$-1. I weight returns equally and include delisting returns. If a firm is delisted for cause (delisting code between 400 and 591) and has a missing delisting return, I assume a delisting return of -30\% following Shumway (1997). Market is the value-weighted return on all NYSE, AMEX, and NASDAQ stocks minus the onemonth Treasury bill rate. Dur is cash flow duration. RIOR is the residual in a cross sectional regression of the fraction of shares held by institutions on size. Institutional ownership information is obtained from the Thomson Reuters $13 F$ database. Financial statement data come from Compustat. For missing Compustat book equity values, I use the Moody's book equity information collected by Davis et al. (2000). I only use stocks above the $20^{\text {th }}$ size percentile.

\begin{tabular}{|c|c|c|c|c|c|c|c|}
\hline & & Low Dur & D2 & D3 & $\mathrm{D} 4$ & High Dur & D1-D5 \\
\hline \multirow{12}{*}{ 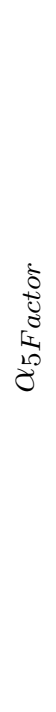 } & Low RIOR & 0.23 & 0.14 & 0.08 & -0.04 & -0.43 & 0.66 \\
\hline & & $(0.14)$ & $(0.13)$ & $(0.11)$ & $(0.14)$ & $(0.23)$ & $(0.19)$ \\
\hline & RIOR2 & 0.17 & 0.07 & 0.02 & 0.07 & -0.07 & 0.24 \\
\hline & & $(0.12)$ & $(0.09)$ & $(0.09)$ & $(0.09)$ & $(0.17)$ & $(0.16)$ \\
\hline & RIOR3 & 0.13 & -0.04 & 0.07 & 0.12 & 0.05 & 0.08 \\
\hline & & $(0.11)$ & $(0.09)$ & $(0.09)$ & $(0.10)$ & $(0.18)$ & $(0.18)$ \\
\hline & RIOR4 & 0.12 & 0.02 & -0.01 & -0.01 & 0.14 & -0.02 \\
\hline & & $(0.11)$ & $(0.09)$ & $(0.10)$ & $(0.11)$ & $(0.20)$ & $(0.19)$ \\
\hline & High RIOR & 0.05 & 0.03 & 0.02 & 0.05 & 0.40 & -0.35 \\
\hline & & $(0.13)$ & $(0.11)$ & $(0.12)$ & $(0.13)$ & $(0.20)$ & $(0.20)$ \\
\hline & RIOR1-RIOR5 & 0.17 & 0.11 & 0.06 & -0.09 & -0.83 & 1.01 \\
\hline & & $(0.14)$ & $(0.13)$ & $(0.12)$ & $(0.14)$ & $(0.23)$ & $(0.24)$ \\
\hline
\end{tabular}




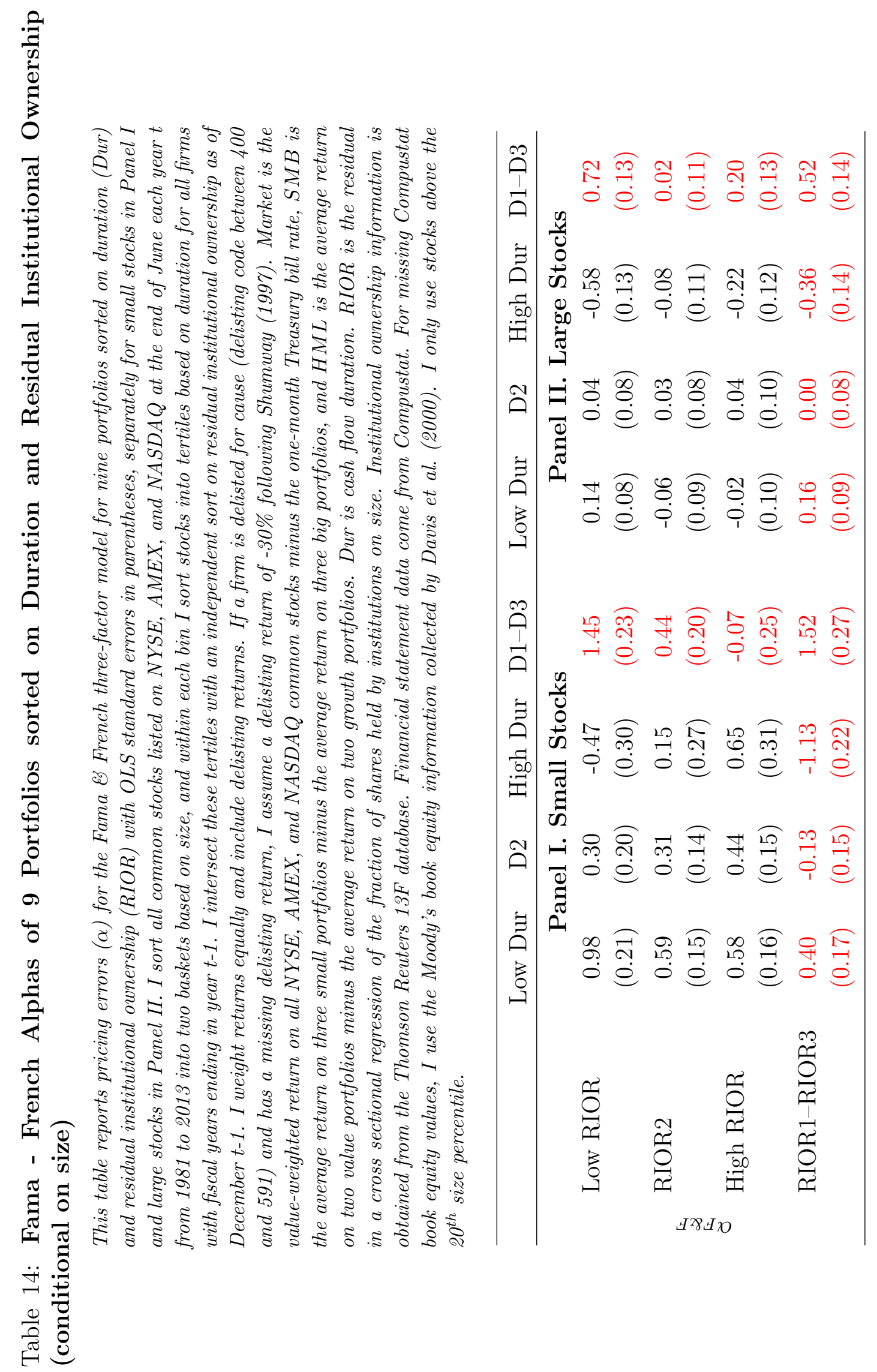




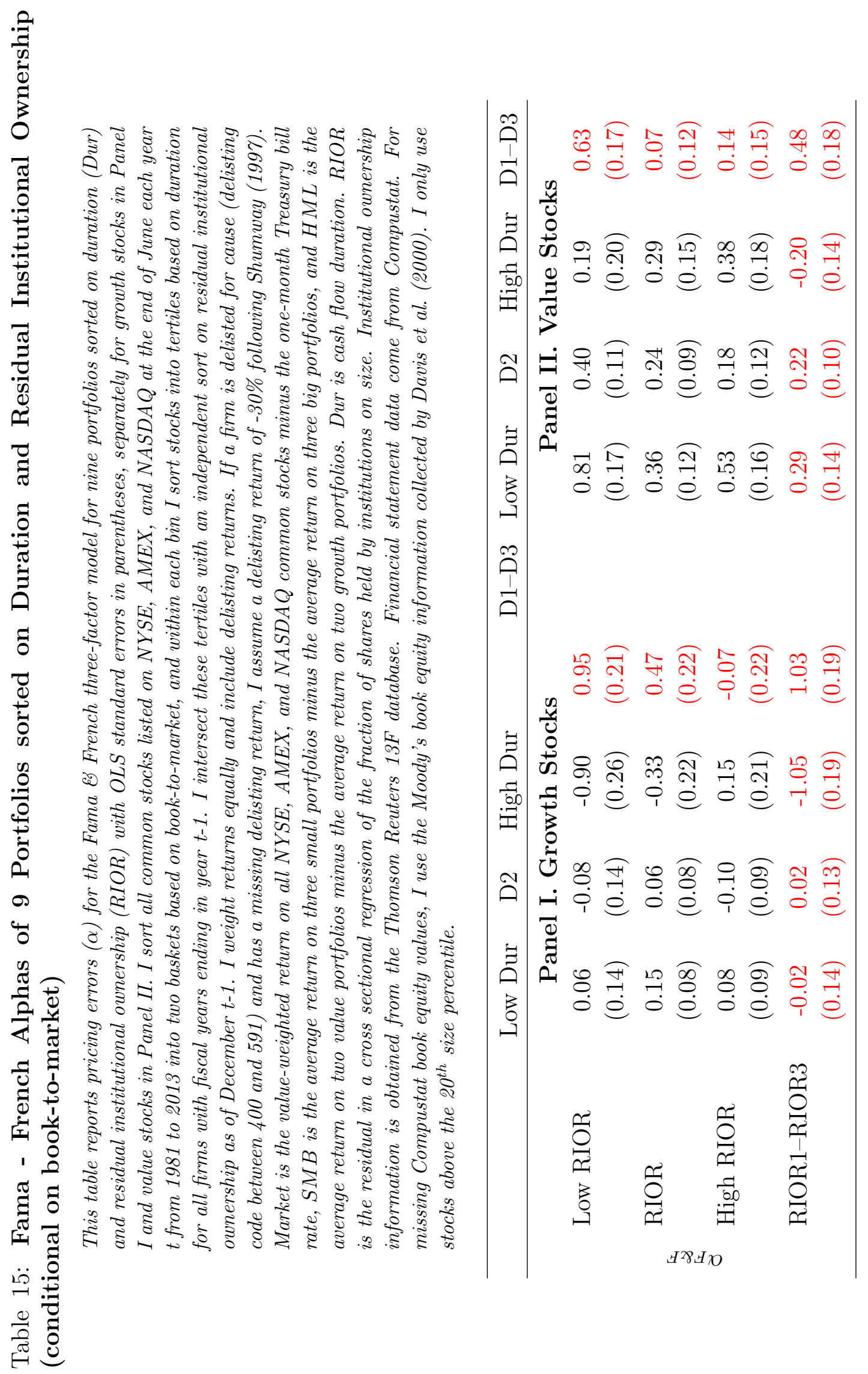


Online Appendix:

Cash Flow Duration and

the Term Structure of Equity Returns

Michael Weber

Not for Publication 


\section{Table A.1: Firm Names}

This table reports five exemplary firm names for companies in the low- and high-duration portfolio in 1996 and 2004.

\begin{tabular}{|c|c|c|c|}
\hline \multicolumn{2}{|c|}{ Panel I. 1996} & \multicolumn{2}{|c|}{ Panel II. 2004} \\
\hline Low Duration & High Duration & Low Duration & High Duration \\
\hline Adolph Coors & EA Industries & Adolph Coors & Enzo Biochem \\
\hline Continental & Peoplesoft & Continental & Adobe Systems \\
\hline Chesapeake & America Online & Chesapeake & Neurocrine Bioscs \\
\hline United Industrial & Symantec & General Motors & Penwest Pharma \\
\hline Amcast Industrial & McAfee & SCS Transportation & Martek Bioscs \\
\hline
\end{tabular}




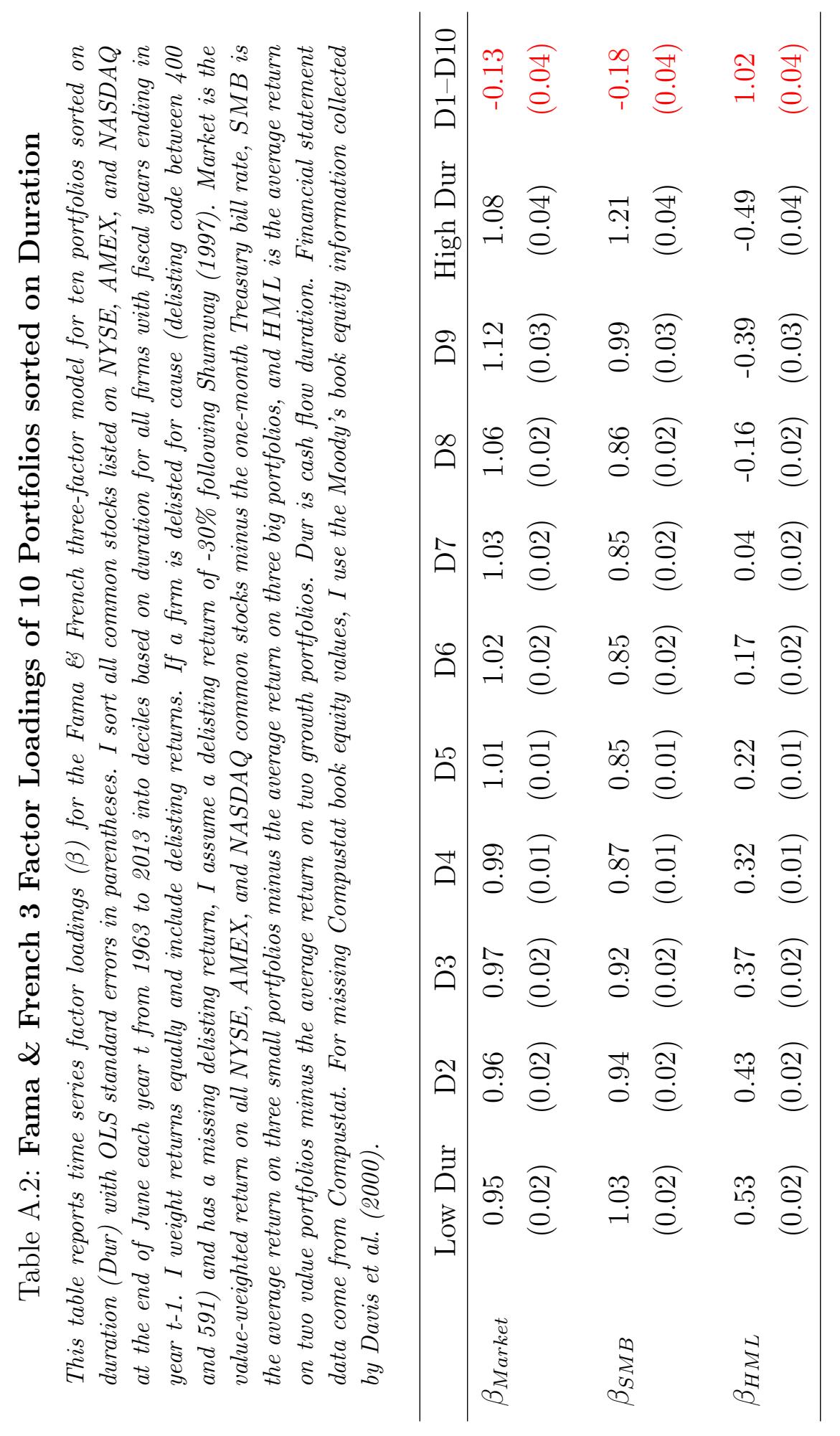




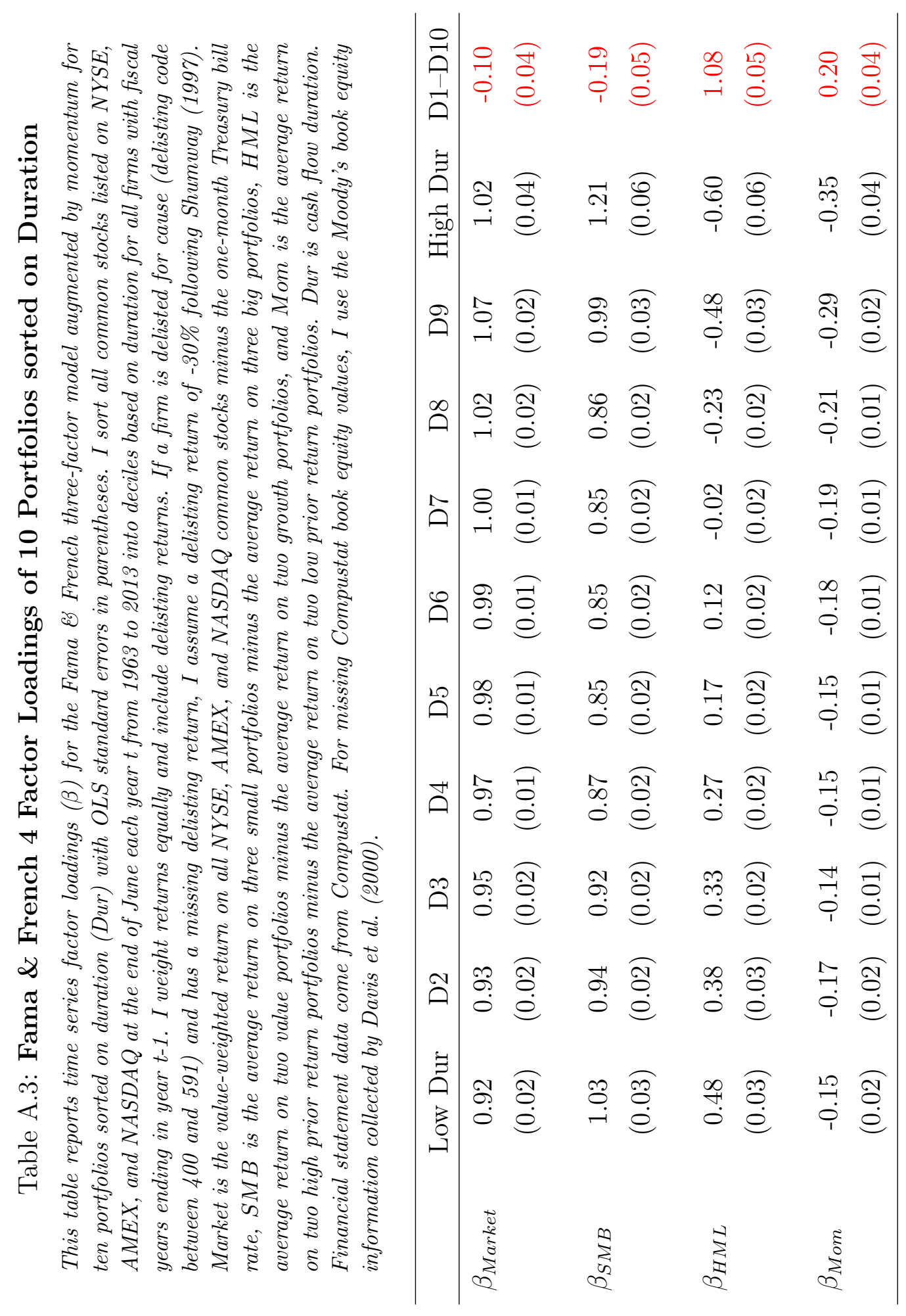




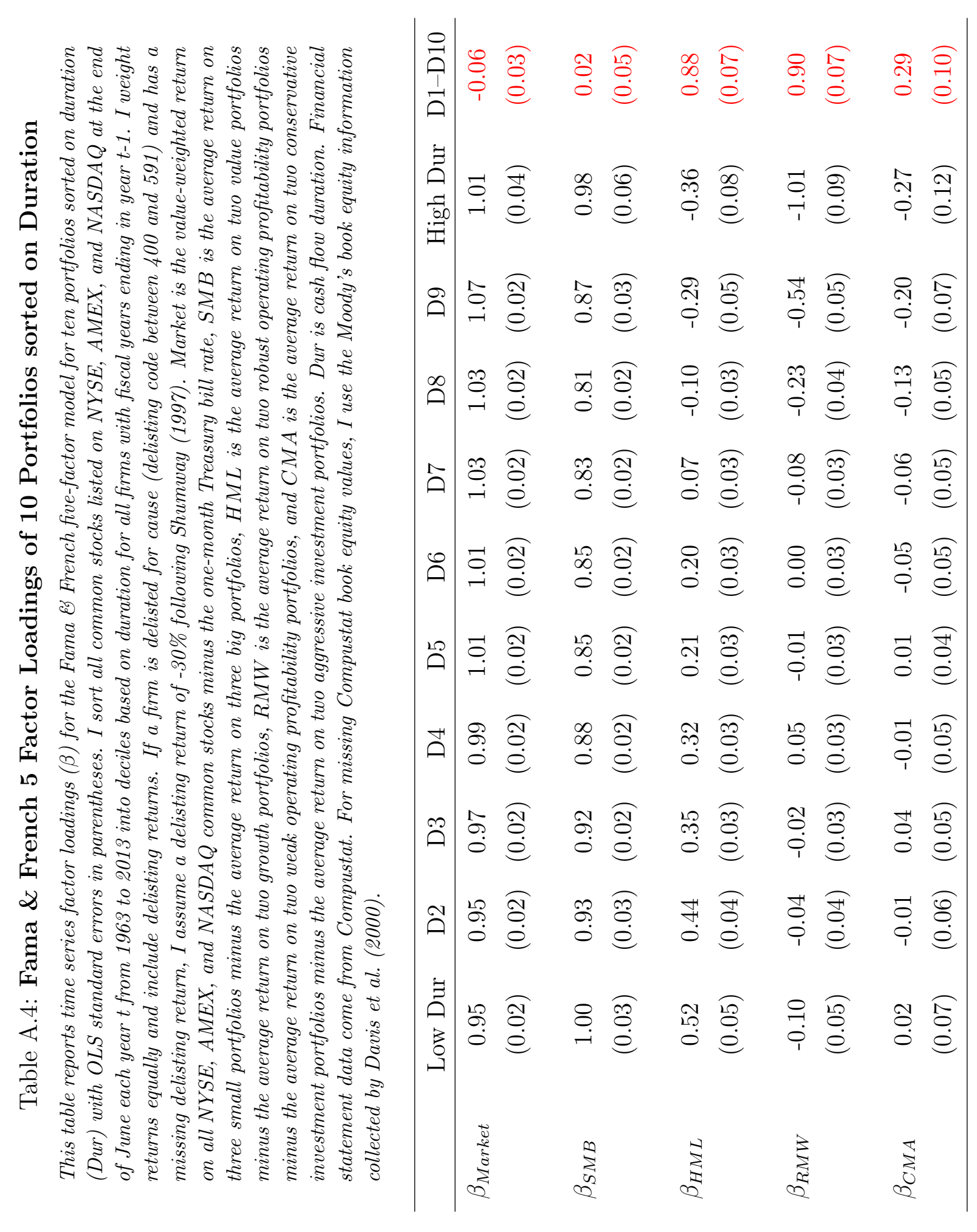


Table A.5: CAPM Betas of 25 Portfolios sorted on Duration and Residual Institutional Ownership

This table reports time series factor loadings ( $\beta$ ) for the CAPM for twenty-five portfolios sorted on duration (Dur) and residual institutional ownership (RIOR) with OLS standard errors in parentheses. I sort all common stocks listed on NYSE, AMEX, and NASDAQ at the end of June each year $t$ from 1981 to 2013 into quintiles based on duration for all firms with fiscal years ending in year $t$-1. I intersect these quintiles with an independent sort on residual institutional ownership as of December $t$-1. I weight returns equally and include delisting returns. If a firm is delisted for cause (delisting code between 400 and 591) and has a missing delisting return, I assume a delisting return of -30\% following Shumway (1997). Market is the value-weighted return on all NYSE, AMEX, and NASDAQ common stocks minus the one-month Treasury bill rate. Dur is cash flow duration. Financial statement data come from Compustat. For missing Compustat book equity values, I use the Moody's book equity information collected by Davis et al. (2000). I only use stocks above the $20^{\text {th }}$ size percentile.

\begin{tabular}{|c|c|c|c|c|c|c|c|}
\hline & & Low Dur & D2 & D3 & D4 & High Dur & D1-D5 \\
\hline \multirow{6}{*}{ 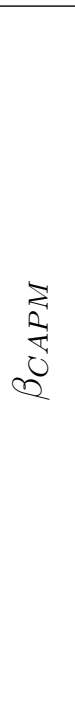 } & Low RIOR & $\begin{array}{c}1.01 \\
(0.04)\end{array}$ & $\begin{array}{c}1.05 \\
(0.04)\end{array}$ & $\begin{array}{c}1.08 \\
(0.03)\end{array}$ & $\begin{array}{c}1.20 \\
(0.04)\end{array}$ & $\begin{array}{c}1.46 \\
(0.07)\end{array}$ & $\begin{array}{l}-0.45 \\
(0.06)\end{array}$ \\
\hline & RIOR2 & $\begin{array}{c}1.06 \\
(0.04)\end{array}$ & $\begin{array}{c}1.09 \\
(0.03)\end{array}$ & $\begin{array}{c}1.12 \\
(0.03)\end{array}$ & $\begin{array}{c}1.16 \\
(0.03)\end{array}$ & $\begin{array}{c}1.47 \\
(0.06)\end{array}$ & $\begin{array}{l}-0.41 \\
(0.05)\end{array}$ \\
\hline & RIOR3 & $\begin{array}{c}1.06 \\
(0.04)\end{array}$ & $\begin{array}{c}1.09 \\
(0.03)\end{array}$ & $\begin{array}{c}1.11 \\
(0.03)\end{array}$ & $\begin{array}{c}1.21 \\
(0.03)\end{array}$ & $\begin{array}{c}1.47 \\
(0.06)\end{array}$ & $\begin{array}{l}-0.41 \\
(0.05)\end{array}$ \\
\hline & RIOR4 & $\begin{array}{c}1.01 \\
(0.04)\end{array}$ & $\begin{array}{c}1.09 \\
(0.04)\end{array}$ & $\begin{array}{c}1.15 \\
(0.03)\end{array}$ & $\begin{array}{c}1.26 \\
(0.04)\end{array}$ & $\begin{array}{c}1.45 \\
(0.06)\end{array}$ & $\begin{array}{l}-0.44 \\
(0.06)\end{array}$ \\
\hline & High RIOR & $\begin{array}{c}1.05 \\
(0.04)\end{array}$ & $\begin{array}{c}1.10 \\
(0.04)\end{array}$ & $\begin{array}{c}1.14 \\
(0.04)\end{array}$ & $\begin{array}{c}1.22 \\
(0.04)\end{array}$ & $\begin{array}{c}1.43 \\
(0.06)\end{array}$ & $\begin{array}{l}-0.38 \\
(0.05)\end{array}$ \\
\hline & RIOR1-RIOR5 & $\begin{array}{l}-0.04 \\
(0.03)\end{array}$ & $\begin{array}{l}-0.05 \\
(0.03)\end{array}$ & $\begin{array}{l}-0.06 \\
(0.03)\end{array}$ & $\begin{array}{l}-0.02 \\
(0.03)\end{array}$ & $\begin{array}{c}0.03 \\
(0.05)\end{array}$ & $\begin{array}{l}-0.07 \\
(0.05)\end{array}$ \\
\hline
\end{tabular}


Table A.6: Fama \& French Factor loadings of 25 Portfolios sorted on Duration and Residual Institutional Ownership

This table reports time series factor loadings ( $\beta$ ) for the Fama $\&$ French three-factor model for twenty-five portfolios sorted on duration (Dur) and residual institutional ownership (RIOR) with OLS standard errors in parentheses. I sort all common stocks listed on NYSE, $A M E X$, and NASDAQ at the end of June each year $t$ from 1981 to 2013 into quintiles based on duration for all firms with fiscal years ending in year t-1. I intersect these quintiles with an independent sort on residual institutional ownership as of December $t$-1. I weight returns equally and include delisting returns. If a firm is delisted for cause (delisting code between 400 and 591) and has a missing delisting return, I assume a delisting return of -30\% following Shumway (1997). Market is the value-weighted return on all NYSE, AMEX, and NASDAQ common stocks minus the one-month Treasury bill rate, $S M B$ is the average return on three small portfolios minus the average return on three big portfolios, and $H M L$ is the average return on two value portfolios minus the average return on two growth portfolios. Dur is cash flow duration. Financial statement data come from Compustat. For missing Compustat book equity values, I use the Moody's book equity information collected by Davis et al. (2000). I only use stocks above the $20^{\text {th }}$ size percentile.

\begin{tabular}{|c|c|c|c|c|c|c|c|}
\hline & & Low Dur & D2 & D3 & $\mathrm{D} 4$ & High Dur & $\mathrm{D} 1-\mathrm{D} 5$ \\
\hline \multirow{5}{*}{ 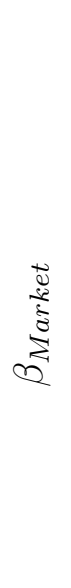 } & Low RIOR & $\begin{array}{c}0.98 \\
(0.03)\end{array}$ & $\begin{array}{c}1.00 \\
(0.03)\end{array}$ & $\begin{array}{c}1.00 \\
(0.03)\end{array}$ & $\begin{array}{c}1.05 \\
(0.03)\end{array}$ & $\begin{array}{c}1.18 \\
(0.06)\end{array}$ & $\begin{array}{l}-0.20 \\
(0.05)\end{array}$ \\
\hline & RIOR2 & $\begin{array}{c}1.04 \\
(0.03)\end{array}$ & $\begin{array}{c}1.05 \\
(0.02)\end{array}$ & $\begin{array}{c}1.07 \\
(0.02)\end{array}$ & $\begin{array}{c}1.06 \\
(0.02)\end{array}$ & $\begin{array}{c}1.22 \\
(0.04)\end{array}$ & $\begin{array}{l}-0.17 \\
(0.04)\end{array}$ \\
\hline & RIOR3 & $\begin{array}{c}1.07 \\
(0.02)\end{array}$ & $\begin{array}{c}1.09 \\
(0.02)\end{array}$ & $\begin{array}{c}1.06 \\
(0.02)\end{array}$ & $\begin{array}{c}1.10 \\
(0.02)\end{array}$ & $\begin{array}{c}1.21 \\
(0.04)\end{array}$ & $\begin{array}{l}-0.14 \\
(0.04)\end{array}$ \\
\hline & RIOR4 & $\begin{array}{c}1.01 \\
(0.02)\end{array}$ & $\begin{array}{c}1.05 \\
(0.02)\end{array}$ & $\begin{array}{c}1.09 \\
(0.02)\end{array}$ & $\begin{array}{c}1.13 \\
(0.02)\end{array}$ & $\begin{array}{c}1.17 \\
(0.05)\end{array}$ & $\begin{array}{l}-0.17 \\
(0.05)\end{array}$ \\
\hline & High RIOR & $\begin{array}{c}1.06 \\
(0.03)\end{array}$ & $\begin{array}{c}1.05 \\
(0.02)\end{array}$ & $\begin{array}{c}1.06 \\
(0.03)\end{array}$ & $\begin{array}{c}1.07 \\
(0.03)\end{array}$ & $\begin{array}{c}1.21 \\
(0.05)\end{array}$ & $\begin{array}{l}-0.16 \\
(0.05)\end{array}$ \\
\hline \multirow{7}{*}{$\sum_{w^{2}}^{\infty}$} & RIOR1-RIOR5 & $\begin{array}{l}-0.08 \\
(0.03)\end{array}$ & $\begin{array}{l}-0.05 \\
(0.03)\end{array}$ & $\begin{array}{l}-0.06 \\
(0.03)\end{array}$ & $\begin{array}{l}-0.02 \\
(0.03)\end{array}$ & $\begin{array}{l}-0.03 \\
(0.05)\end{array}$ & $\begin{array}{l}-0.05 \\
(0.05)\end{array}$ \\
\hline & Low RIOR & $\begin{array}{c}0.87 \\
(0.05)\end{array}$ & $\begin{array}{c}0.68 \\
(0.04)\end{array}$ & $\begin{array}{c}0.74 \\
(0.04)\end{array}$ & $\begin{array}{c}0.78 \\
(0.05)\end{array}$ & $\begin{array}{c}1.21 \\
(0.08)\end{array}$ & $\begin{array}{l}-0.34 \\
(0.07)\end{array}$ \\
\hline & RIOR2 & $\begin{array}{c}0.83 \\
(0.04)\end{array}$ & $\begin{array}{c}0.70 \\
(0.03)\end{array}$ & $\begin{array}{c}0.61 \\
(0.03)\end{array}$ & $\begin{array}{c}0.56 \\
(0.03)\end{array}$ & $\begin{array}{c}1.05 \\
(0.06)\end{array}$ & $\begin{array}{l}-0.22 \\
(0.06)\end{array}$ \\
\hline & RIOR3 & $\begin{array}{c}0.83 \\
(0.04)\end{array}$ & $\begin{array}{c}0.65 \\
(0.03)\end{array}$ & $\begin{array}{c}0.68 \\
(0.03)\end{array}$ & $\begin{array}{c}0.65 \\
(0.03)\end{array}$ & $\begin{array}{c}1.08 \\
(0.06)\end{array}$ & $\begin{array}{l}-0.25 \\
(0.06)\end{array}$ \\
\hline & RIOR4 & $\begin{array}{c}0.86 \\
(0.04)\end{array}$ & $\begin{array}{c}0.90 \\
(0.03)\end{array}$ & $\begin{array}{c}0.79 \\
(0.04)\end{array}$ & $\begin{array}{c}0.84 \\
(0.04)\end{array}$ & $\begin{array}{c}1.15 \\
(0.07)\end{array}$ & $\begin{array}{l}-0.29 \\
(0.07)\end{array}$ \\
\hline & High RIOR & $\begin{array}{c}1.00 \\
(0.04)\end{array}$ & $\begin{array}{c}0.99 \\
(0.04)\end{array}$ & $\begin{array}{c}0.96 \\
(0.04)\end{array}$ & $\begin{array}{c}0.92 \\
(0.04)\end{array}$ & $\begin{array}{c}1.17 \\
(0.07)\end{array}$ & $\begin{array}{l}-0.16 \\
(0.07)\end{array}$ \\
\hline & RIOR1-RIOR5 & $\begin{array}{l}-0.13 \\
(0.05)\end{array}$ & $\begin{array}{l}-0.31 \\
(0.04)\end{array}$ & $\begin{array}{l}-0.22 \\
(0.04)\end{array}$ & $\begin{array}{l}-0.14 \\
(0.05)\end{array}$ & $\begin{array}{c}0.04 \\
(0.08)\end{array}$ & $\begin{array}{l}-0.17 \\
(0.08)\end{array}$ \\
\hline
\end{tabular}


Table A.7: Continued from Previous Page

\begin{tabular}{lcccccc}
\hline & Low Dur & D2 & D3 & D4 & High Dur & D1-D5 \\
\hline Low RIOR & 0.40 & 0.20 & 0.08 & -0.18 & -0.52 & 0.92 \\
& $(0.05)$ & $(0.04)$ & $(0.04)$ & $(0.05)$ & $(0.08)$ & $(0.07)$ \\
RIOR2 & 0.44 & 0.27 & 0.16 & -0.11 & -0.51 & 0.95 \\
& $(0.04)$ & $(0.03)$ & $(0.03)$ & $(0.03)$ & $(0.06)$ & $(0.06)$ \\
\multirow{2}{*}{ RIOR3 } & 0.56 & 0.44 & 0.18 & -0.12 & -0.52 & 1.08 \\
& $(0.04)$ & $(0.03)$ & $(0.03)$ & $(0.03)$ & $(0.06)$ & $(0.06)$ \\
RIOR4 & 0.51 & 0.40 & 0.22 & -0.10 & -0.54 & 1.06 \\
& $(0.04)$ & $(0.03)$ & $(0.04)$ & $(0.04)$ & $(0.07)$ & $(0.07)$ \\
High RIOR & 0.67 & 0.38 & 0.27 & -0.09 & -0.27 & 0.94 \\
& $(0.04)$ & $(0.04)$ & $(0.04)$ & $(0.04)$ & $(0.07)$ & $(0.07)$ \\
RIOR1-RIOR5 & -0.27 & -0.18 & -0.18 & -0.08 & -0.24 & -0.02 \\
& $(0.05)$ & $(0.04)$ & $(0.04)$ & $(0.05)$ & $(0.08)$ & $(0.08)$ \\
\hline
\end{tabular}


Table A.8: Four Factor loadings of 25 Portfolios sorted on Duration and Residual Institutional Ownership

This table reports time series factor loadings $(\beta)$ for the Fama $\&$ French three-factor model augmented with momentum for twenty-five portfolios sorted on duration (Dur) and residual institutional ownership (RIOR) with OLS standard errors in parentheses. I sort all common stocks listed on NYSE, AMEX, and NASDAQ at the end of June each year $t$ from 1981 to 2013 into quintiles based on duration for all firms with fiscal years ending in year $t$-1. I intersect these quintiles with an independent sort on residual institutional ownership as of December $t-1$. I weight returns equally and include delisting returns. If a firm is delisted for cause (delisting code between 400 and 591) and has a missing delisting return, I assume a delisting return of -30\% following Shumway (1997). Market is the value-weighted return on all NYSE, AMEX, and NASDAQ common stocks minus the one-month Treasury bill rate, $S M B$ is the average return on three small portfolios minus the average return on three big portfolios, $H M L$ is the average return on two value portfolios minus the average return on two growth portfolios, and Mom is the average return on two high prior return portfolios minus the average return on two low prior return portfolios. Dur is cash flow duration. Financial statement data come from Compustat. For missing Compustat book equity values, I use the Moody's book equity information collected by Davis et al. (2000). I only use stocks above the $20^{\text {th }}$ size percentile.

\begin{tabular}{|c|c|c|c|c|c|c|c|}
\hline & & Low Dur & D2 & D3 & D4 & High Dur & D1-D5 \\
\hline \multirow{6}{*}{ 范 } & Low RIOR & $\begin{array}{c}0.91 \\
(0.03)\end{array}$ & $\begin{array}{c}0.94 \\
(0.03)\end{array}$ & $\begin{array}{c}0.94 \\
(0.02)\end{array}$ & $\begin{array}{c}0.97 \\
(0.03)\end{array}$ & $\begin{array}{c}1.05 \\
(0.05)\end{array}$ & $\begin{array}{l}-0.13 \\
(0.05)\end{array}$ \\
\hline & RIOR2 & $\begin{array}{c}0.99 \\
(0.02)\end{array}$ & $\begin{array}{c}1.01 \\
(0.02)\end{array}$ & $\begin{array}{c}1.02 \\
(0.02)\end{array}$ & $\begin{array}{c}1.01 \\
(0.02)\end{array}$ & $\begin{array}{c}1.11 \\
(0.04)\end{array}$ & $\begin{array}{c}-0.12 \\
(0.04)\end{array}$ \\
\hline & RIOR3 & $\begin{array}{c}1.02 \\
(0.02)\end{array}$ & $\begin{array}{c}1.05 \\
(0.02)\end{array}$ & $\begin{array}{c}1.02 \\
(0.02)\end{array}$ & $\begin{array}{c}1.04 \\
(0.02)\end{array}$ & $\begin{array}{c}1.12 \\
(0.04)\end{array}$ & $\begin{array}{l}-0.10 \\
(0.04)\end{array}$ \\
\hline & RIOR4 & $\begin{array}{c}0.96 \\
(0.02)\end{array}$ & $\begin{array}{c}1.01 \\
(0.02)\end{array}$ & $\begin{array}{c}1.04 \\
(0.02)\end{array}$ & $\begin{array}{c}1.06 \\
(0.02)\end{array}$ & $\begin{array}{c}1.07 \\
(0.04)\end{array}$ & $\begin{array}{c}-0.11 \\
(0.05)\end{array}$ \\
\hline & High RIOR & $\begin{array}{c}0.99 \\
(0.03)\end{array}$ & $\begin{array}{c}1.00 \\
(0.02)\end{array}$ & $\begin{array}{c}1.00 \\
(0.02)\end{array}$ & $\begin{array}{c}1.02 \\
(0.03)\end{array}$ & $\begin{array}{c}1.14 \\
(0.04)\end{array}$ & $\begin{array}{l}-0.14 \\
(0.05)\end{array}$ \\
\hline & RIOR1-RIOR5 & $\begin{array}{l}-0.08 \\
(0.03)\end{array}$ & $\begin{array}{l}-0.06 \\
(0.03)\end{array}$ & $\begin{array}{l}-0.06 \\
(0.03)\end{array}$ & $\begin{array}{l}-0.05 \\
(0.03)\end{array}$ & $\begin{array}{l}-0.09 \\
(0.05)\end{array}$ & $\begin{array}{c}0.01 \\
(0.05)\end{array}$ \\
\hline \multirow{6}{*}{ 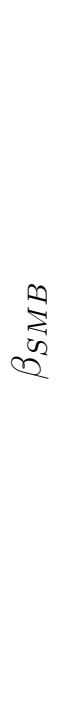 } & Low RIOR & $\begin{array}{c}0.89 \\
(0.04)\end{array}$ & $\begin{array}{c}0.70 \\
(0.04)\end{array}$ & $\begin{array}{c}0.75 \\
(0.03)\end{array}$ & $\begin{array}{c}0.80 \\
(0.04)\end{array}$ & $\begin{array}{c}1.24 \\
(0.07)\end{array}$ & $\begin{array}{l}-0.35 \\
(0.07)\end{array}$ \\
\hline & RIOR2 & $\begin{array}{c}0.84 \\
(0.04)\end{array}$ & $\begin{array}{c}0.71 \\
(0.03)\end{array}$ & $\begin{array}{c}0.62 \\
(0.02)\end{array}$ & $\begin{array}{c}0.57 \\
(0.03)\end{array}$ & $\begin{array}{c}1.08 \\
(0.05)\end{array}$ & $\begin{array}{c}-0.23 \\
(0.06)\end{array}$ \\
\hline & RIOR3 & $\begin{array}{c}0.84 \\
(0.03)\end{array}$ & $\begin{array}{c}0.66 \\
(0.03)\end{array}$ & $\begin{array}{c}0.69 \\
(0.03)\end{array}$ & $\begin{array}{c}0.67 \\
(0.03)\end{array}$ & $\begin{array}{c}1.10 \\
(0.05)\end{array}$ & $\begin{array}{c}-0.26 \\
(0.06)\end{array}$ \\
\hline & RIOR4 & $\begin{array}{c}0.87 \\
(0.03)\end{array}$ & $\begin{array}{c}0.91 \\
(0.03)\end{array}$ & $\begin{array}{c}0.81 \\
(0.03)\end{array}$ & $\begin{array}{c}0.85 \\
(0.03)\end{array}$ & $\begin{array}{c}1.17 \\
(0.06)\end{array}$ & $\begin{array}{l}-0.30 \\
(0.07)\end{array}$ \\
\hline & High RIOR & $\begin{array}{c}1.02 \\
(0.04)\end{array}$ & $\begin{array}{c}1.00 \\
(0.03)\end{array}$ & $\begin{array}{c}0.97 \\
(0.03)\end{array}$ & $\begin{array}{c}0.93 \\
(0.04)\end{array}$ & $\begin{array}{c}1.18 \\
(0.06)\end{array}$ & $\begin{array}{l}-0.17 \\
(0.07)\end{array}$ \\
\hline & RIOR1-RIOR5 & $\begin{array}{l}-0.13 \\
(0.05)\end{array}$ & $\begin{array}{l}-0.30 \\
(0.04) 9\end{array}$ & $\begin{array}{l}-0.22 \\
(0.04)\end{array}$ & $\begin{array}{l}-0.13 \\
(0.05)\end{array}$ & $\begin{array}{c}0.06 \\
(0.08)\end{array}$ & $\begin{array}{l}-0.19 \\
(0.08)\end{array}$ \\
\hline
\end{tabular}


Table A.9: Continued from Previous Page

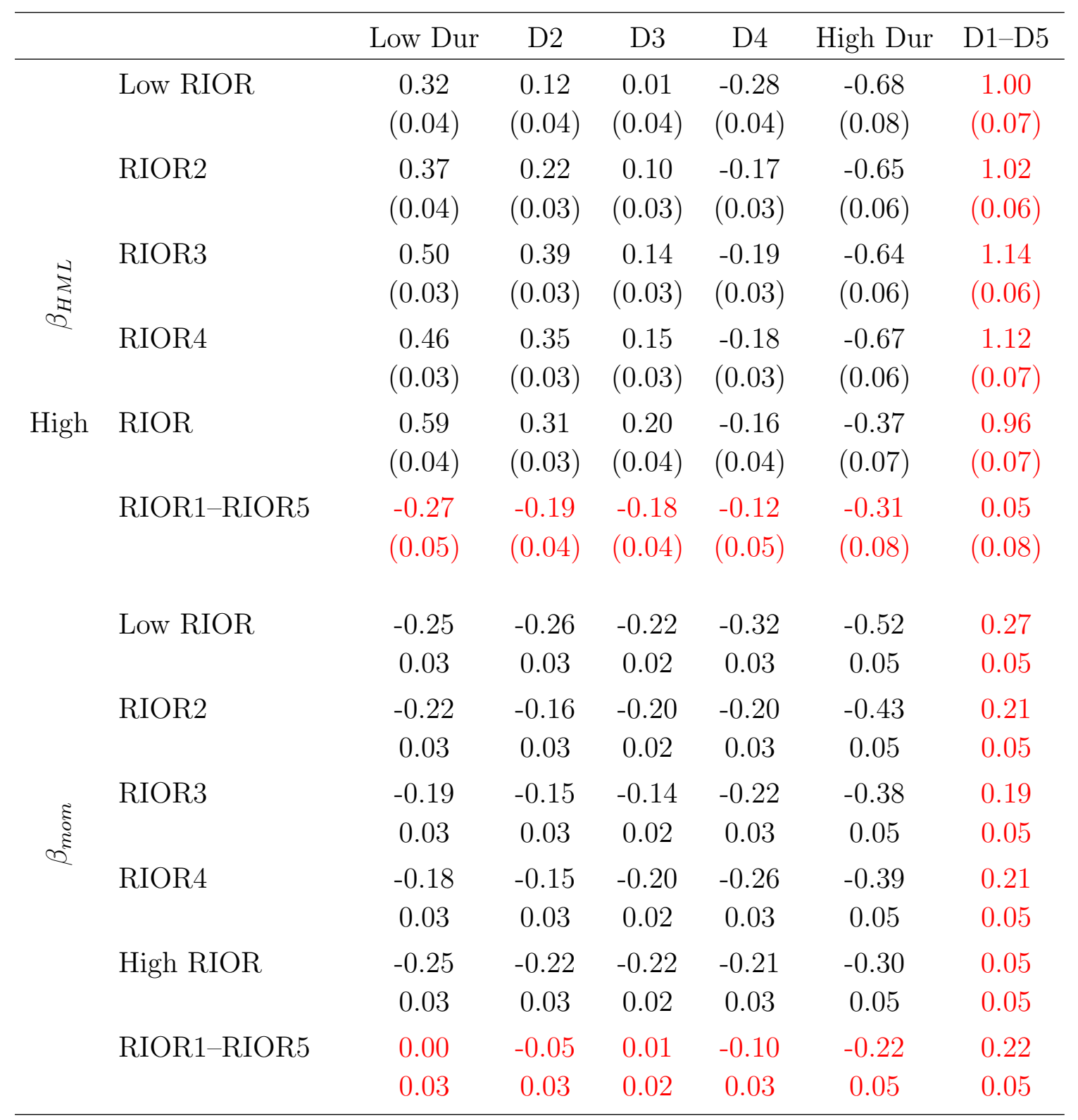


Table A.10: Five Factor loadings of 25 Portfolios sorted on Duration and Residual Institutional Ownership

This table reports time series factor loadings $(\beta)$ for the Fama $\&$ French five-factor model for twenty-five portfolios sorted on duration (Dur) and residual institutional ownership (RIOR) with OLS standard errors in parentheses. I sort all common stocks listed on NYSE, AMEX, and NASDAQ at the end of June each year $t$ from 1981 to 2013 into quintiles based on duration for all firms with fiscal years ending in year -1. I intersect these quintiles with an independent sort on residual institutional ownership as of December $t$-1. I weight returns equally and include delisting returns. If a firm is delisted for cause (delisting code between 400 and 591) and has a missing delisting return, I assume a delisting return of -30\% following Shumway (1997). Market is the value-weighted return on all NYSE, AMEX, and NASDAQ common stocks minus the one-month Treasury bill rate, SMB is the average return on three small portfolios minus the average return on three big portfolios, $H M L$ is the average return on two value portfolios minus the average return on two growth portfolios, $R M W$ is the average return on two robust operating profitability portfolios minus the average return on two weak operating profitability portfolios, and CMA is the average return on two conservative investment portfolios minus the average return on two aggressive investment portfolios. Dur is cash flow duration. Financial statement data come from Compustat. For missing Compustat book equity values, I use the Moody's book equity information collected by Davis et al. (2000). I only use stocks above the $20^{\text {th }}$ size percentile.

\begin{tabular}{|c|c|c|c|c|c|c|c|}
\hline & & Low Dur & D2 & D3 & D4 & High Dur & D1-D5 \\
\hline \multirow{6}{*}{ है } & Low RIOR & $\begin{array}{c}0.96 \\
(0.03)\end{array}$ & $\begin{array}{c}0.98 \\
(0.03)\end{array}$ & $\begin{array}{c}0.98 \\
(0.03)\end{array}$ & $\begin{array}{c}1.00 \\
(0.03)\end{array}$ & $\begin{array}{c}1.04 \\
(0.05)\end{array}$ & $\begin{array}{l}-0.08 \\
(0.04)\end{array}$ \\
\hline & RIOR2 & $\begin{array}{c}1.04 \\
(0.03)\end{array}$ & $\begin{array}{c}1.07 \\
(0.02)\end{array}$ & $\begin{array}{c}1.07 \\
(0.02)\end{array}$ & $\begin{array}{c}1.05 \\
(0.02)\end{array}$ & $\begin{array}{c}1.12 \\
(0.04)\end{array}$ & $\begin{array}{l}-0.08 \\
(0.04)\end{array}$ \\
\hline & RIOR3 & $\begin{array}{c}1.06 \\
(0.03)\end{array}$ & $\begin{array}{c}1.11 \\
(0.02)\end{array}$ & $\begin{array}{c}1.07 \\
(0.02)\end{array}$ & $\begin{array}{c}1.07 \\
(0.02)\end{array}$ & $\begin{array}{c}1.14 \\
(0.04)\end{array}$ & $\begin{array}{l}-0.08 \\
(0.04)\end{array}$ \\
\hline & RIOR4 & $\begin{array}{c}1.01 \\
(0.03)\end{array}$ & $\begin{array}{c}1.07 \\
(0.02)\end{array}$ & $\begin{array}{c}1.10 \\
(0.02)\end{array}$ & $\begin{array}{c}1.09 \\
(0.03)\end{array}$ & $\begin{array}{c}1.10 \\
(0.05)\end{array}$ & $\begin{array}{l}-0.10 \\
(0.05)\end{array}$ \\
\hline & High RIOR & $\begin{array}{c}1.06 \\
(0.03)\end{array}$ & $\begin{array}{c}1.06 \\
(0.03)\end{array}$ & $\begin{array}{c}1.07 \\
(0.03)\end{array}$ & $\begin{array}{c}1.06 \\
(0.03)\end{array}$ & $\begin{array}{c}1.15 \\
(0.05)\end{array}$ & $\begin{array}{l}-0.09 \\
(0.05)\end{array}$ \\
\hline & RIOR1-RIOR5 & $\begin{array}{l}-0.10 \\
(0.03)\end{array}$ & $\begin{array}{l}-0.09 \\
(0.03)\end{array}$ & $\begin{array}{l}-0.09 \\
(0.03)\end{array}$ & $\begin{array}{l}-0.05 \\
(0.03)\end{array}$ & $\begin{array}{l}-0.11 \\
(0.05)\end{array}$ & $\begin{array}{c}0.01 \\
(0.06)\end{array}$ \\
\hline \multirow{6}{*}{$\sum_{\substack{a \\
n^{2}}}^{\infty}$} & Low RIOR & $\begin{array}{c}0.86 \\
(0.05)\end{array}$ & $\begin{array}{c}0.67 \\
(0.05)\end{array}$ & $\begin{array}{c}0.70 \\
(0.04)\end{array}$ & $\begin{array}{c}0.70 \\
(0.05)\end{array}$ & $\begin{array}{c}0.90 \\
(0.08)\end{array}$ & $\begin{array}{l}-0.05 \\
(0.07)\end{array}$ \\
\hline & RIOR2 & $\begin{array}{c}0.86 \\
(0.04)\end{array}$ & $\begin{array}{c}0.74 \\
(0.03)\end{array}$ & $\begin{array}{c}0.63 \\
(0.03)\end{array}$ & $\begin{array}{c}0.55 \\
(0.03)\end{array}$ & $\begin{array}{c}0.83 \\
(0.06)\end{array}$ & $\begin{array}{c}0.03 \\
(0.06)\end{array}$ \\
\hline & RIOR3 & $\begin{array}{c}0.85 \\
(0.04)\end{array}$ & $\begin{array}{c}0.72 \\
(0.03)\end{array}$ & $\begin{array}{c}0.73 \\
(0.03)\end{array}$ & $\begin{array}{c}0.64 \\
(0.03)\end{array}$ & $\begin{array}{c}0.92 \\
(0.06)\end{array}$ & $\begin{array}{l}-0.07 \\
(0.06)\end{array}$ \\
\hline & RIOR4 & $\begin{array}{c}0.88 \\
(0.04)\end{array}$ & $\begin{array}{c}0.95 \\
(0.03)\end{array}$ & $\begin{array}{c}0.85 \\
(0.04)\end{array}$ & $\begin{array}{c}0.80 \\
(0.04)\end{array}$ & $\begin{array}{c}0.96 \\
(0.07)\end{array}$ & $\begin{array}{l}-0.09 \\
(0.07)\end{array}$ \\
\hline & High RIOR & $\begin{array}{c}1.05 \\
(0.05)\end{array}$ & $\begin{array}{c}1.04 \\
(0.04)\end{array}$ & $\begin{array}{c}0.98 \\
(0.04)\end{array}$ & $\begin{array}{c}0.93 \\
(0.05)\end{array}$ & $\begin{array}{c}1.01 \\
(0.07)\end{array}$ & $\begin{array}{c}0.04 \\
(0.07)\end{array}$ \\
\hline & RIOR1-RIOR5 & $\begin{array}{l}-0.19 \\
(0.05)\end{array}$ & $\begin{array}{l}-0.37^{11} \\
(0.05)\end{array}$ & $\begin{array}{l}-0.28 \\
(0.04)\end{array}$ & $\begin{array}{l}-0.23 \\
(0.05)\end{array}$ & $\begin{array}{l}-0.11 \\
(0.08)\end{array}$ & $\begin{array}{l}-0.08 \\
(0.09)\end{array}$ \\
\hline
\end{tabular}


Table A.11: Continued from Previous Page

\begin{tabular}{|c|c|c|c|c|c|c|c|}
\hline & & Low Dur & D2 & D3 & D4 & High Dur & D1-D5 \\
\hline \multirow{5}{*}{ 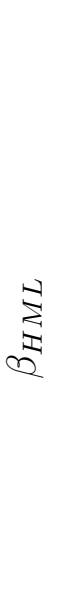 } & Low RIOR & $\begin{array}{c}0.47 \\
(0.06)\end{array}$ & $\begin{array}{c}0.30 \\
(0.06)\end{array}$ & $\begin{array}{c}0.13 \\
(0.05)\end{array}$ & $\begin{array}{l}-0.05 \\
(0.07)\end{array}$ & $\begin{array}{l}-0.17 \\
(0.10)\end{array}$ & $\begin{array}{c}0.64 \\
(0.09)\end{array}$ \\
\hline & RIOR2 & $\begin{array}{c}0.48 \\
(0.05)\end{array}$ & $\begin{array}{c}0.25 \\
(0.04)\end{array}$ & $\begin{array}{c}0.15 \\
(0.04)\end{array}$ & $\begin{array}{l}-0.06 \\
(0.04)\end{array}$ & $\begin{array}{c}-0.28 \\
(0.08)\end{array}$ & $\begin{array}{c}0.76 \\
(0.07)\end{array}$ \\
\hline & RIOR3 & $\begin{array}{c}0.59 \\
(0.05)\end{array}$ & $\begin{array}{c}0.42 \\
(0.04)\end{array}$ & $\begin{array}{c}0.15 \\
(0.04)\end{array}$ & $\begin{array}{l}-0.04 \\
(0.04)\end{array}$ & $\begin{array}{l}-0.35 \\
(0.08)\end{array}$ & $\begin{array}{c}0.94 \\
(0.08)\end{array}$ \\
\hline & RIOR4 & $\begin{array}{c}0.53 \\
(0.05)\end{array}$ & $\begin{array}{c}0.34 \\
(0.04)\end{array}$ & $\begin{array}{c}0.21 \\
(0.05)\end{array}$ & $\begin{array}{c}0.02 \\
(0.05)\end{array}$ & $\begin{array}{l}-0.39 \\
(0.09)\end{array}$ & $\begin{array}{c}0.92 \\
(0.09)\end{array}$ \\
\hline & High RIOR & $\begin{array}{c}0.69 \\
(0.06)\end{array}$ & $\begin{array}{c}0.37 \\
(0.05)\end{array}$ & $\begin{array}{c}0.25 \\
(0.05)\end{array}$ & $\begin{array}{l}-0.02 \\
(0.06)\end{array}$ & $\begin{array}{l}-0.13 \\
(0.09)\end{array}$ & $\begin{array}{c}0.82 \\
(0.09)\end{array}$ \\
\hline \multirow{7}{*}{ 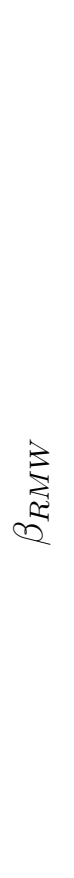 } & RIOR1-RIOR5 & $\begin{array}{l}-0.22 \\
(0.06)\end{array}$ & $\begin{array}{l}-0.06 \\
(0.06)\end{array}$ & $\begin{array}{l}-0.11 \\
(0.06)\end{array}$ & $\begin{array}{l}-0.03 \\
(0.06)\end{array}$ & $\begin{array}{l}-0.04 \\
(0.10)\end{array}$ & $\begin{array}{l}-0.18 \\
(0.11)\end{array}$ \\
\hline & Low RIOR & $\begin{array}{l}-0.08 \\
(0.07)\end{array}$ & $\begin{array}{c}-0.08 \\
(0.06)\end{array}$ & $\begin{array}{l}-0.13 \\
(0.05)\end{array}$ & $\begin{array}{l}-0.33 \\
(0.07)\end{array}$ & $\begin{array}{l}-1.13 \\
(0.11)\end{array}$ & $\begin{array}{c}1.05 \\
(0.09)\end{array}$ \\
\hline & RIOR2 & $\begin{array}{c}0.05 \\
(0.06)\end{array}$ & $\begin{array}{c}0.12 \\
(0.04)\end{array}$ & $\begin{array}{c}0.07 \\
(0.04)\end{array}$ & $\begin{array}{l}-0.04 \\
(0.04)\end{array}$ & $\begin{array}{l}-0.81 \\
(0.08)\end{array}$ & $\begin{array}{c}0.87 \\
(0.08)\end{array}$ \\
\hline & RIOR3 & $\begin{array}{c}0.04 \\
(0.05)\end{array}$ & $\begin{array}{c}0.24 \\
(0.04)\end{array}$ & $\begin{array}{c}0.17 \\
(0.04)\end{array}$ & $\begin{array}{l}-0.08 \\
(0.05)\end{array}$ & $\begin{array}{l}-0.59 \\
(0.08)\end{array}$ & $\begin{array}{c}0.63 \\
(0.09)\end{array}$ \\
\hline & RIOR4 & $\begin{array}{c}0.06 \\
(0.05)\end{array}$ & $\begin{array}{c}0.18 \\
(0.04)\end{array}$ & $\begin{array}{c}0.19 \\
(0.05)\end{array}$ & $\begin{array}{c}-0.17 \\
(0.05)\end{array}$ & $\begin{array}{c}-0.66 \\
(0.09)\end{array}$ & $\begin{array}{c}0.71 \\
(0.09)\end{array}$ \\
\hline & High RIOR & $\begin{array}{c}0.12 \\
(0.06)\end{array}$ & $\begin{array}{c}0.18 \\
(0.05)\end{array}$ & $\begin{array}{c}0.07 \\
(0.06)\end{array}$ & $\begin{array}{l}-0.01 \\
(0.06)\end{array}$ & $\begin{array}{l}-0.56 \\
(0.09)\end{array}$ & $\begin{array}{c}0.68 \\
(0.09)\end{array}$ \\
\hline & RIOR1-RIOR5 & $\begin{array}{c}-0.20 \\
(0.06)\end{array}$ & $\begin{array}{c}-0.26 \\
(0.06)\end{array}$ & $\begin{array}{c}-0.21 \\
(0.06)\end{array}$ & $\begin{array}{c}-0.32 \\
(0.06)\end{array}$ & $\begin{array}{l}-0.57 \\
(0.11)\end{array}$ & $\begin{array}{c}0.37 \\
(0.11)\end{array}$ \\
\hline
\end{tabular}


Table A.12: Continued from Previous Page

\begin{tabular}{|c|c|c|c|c|c|c|c|}
\hline & & Low Dur & D2 & D3 & $\mathrm{D} 4$ & High Dur & D1-D5 \\
\hline \multirow{6}{*}{$\sum_{0}^{J}$} & Low RIOR & $\begin{array}{l}-0.12 \\
(0.09)\end{array}$ & $\begin{array}{l}-0.21 \\
(0.09)\end{array}$ & $\begin{array}{l}-0.07 \\
(0.08)\end{array}$ & $\begin{array}{l}-0.18 \\
(0.10)\end{array}$ & $\begin{array}{l}-0.41 \\
(0.15)\end{array}$ & $\begin{array}{c}0.28 \\
(0.13)\end{array}$ \\
\hline & RIOR2 & $\begin{array}{l}-0.12 \\
(0.08)\end{array}$ & $\begin{array}{c}0.00 \\
(0.06)\end{array}$ & $\begin{array}{l}-0.01 \\
(0.06)\end{array}$ & $\begin{array}{l}-0.10 \\
(0.06)\end{array}$ & $\begin{array}{l}-0.25 \\
(0.11)\end{array}$ & $\begin{array}{c}0.13 \\
(0.11)\end{array}$ \\
\hline & RIOR3 & $\begin{array}{l}-0.10 \\
(0.07)\end{array}$ & $\begin{array}{l}-0.05 \\
(0.06)\end{array}$ & $\begin{array}{c}0.01 \\
(0.06)\end{array}$ & $\begin{array}{l}-0.16 \\
(0.06)\end{array}$ & $\begin{array}{l}-0.18 \\
(0.12)\end{array}$ & $\begin{array}{c}0.08 \\
(0.12)\end{array}$ \\
\hline & RIOR4 & $\begin{array}{l}-0.05 \\
(0.07)\end{array}$ & $\begin{array}{c}0.07 \\
(0.06)\end{array}$ & $\begin{array}{l}-0.05 \\
(0.07)\end{array}$ & $\begin{array}{l}-0.22 \\
(0.07)\end{array}$ & $\begin{array}{l}-0.12 \\
(0.13)\end{array}$ & $\begin{array}{c}0.07 \\
(0.13)\end{array}$ \\
\hline & High RIOR & $\begin{array}{l}-0.09 \\
(0.09)\end{array}$ & $\begin{array}{l}-0.04 \\
(0.07)\end{array}$ & $\begin{array}{c}0.02 \\
(0.08)\end{array}$ & $\begin{array}{l}-0.16 \\
(0.09)\end{array}$ & $\begin{array}{l}-0.13 \\
(0.13)\end{array}$ & $\begin{array}{c}0.04 \\
(0.13)\end{array}$ \\
\hline & RIOR1-RIOR5 & $\begin{array}{l}-0.03 \\
(0.09)\end{array}$ & $\begin{array}{l}-0.17 \\
(0.09)\end{array}$ & $\begin{array}{l}-0.09 \\
(0.08)\end{array}$ & $\begin{array}{l}-0.02 \\
(0.09)\end{array}$ & $\begin{array}{l}-0.28 \\
(0.15)\end{array}$ & $\begin{array}{c}0.25 \\
(0.16)\end{array}$ \\
\hline
\end{tabular}

